University of Nebraska - Lincoln

DigitalCommons@University of Nebraska - Lincoln

$1-1-2022$

\title{
Creole Sketches
}

Lafcadio Hearn

New Orleans Daily Item

Charles Woodward Hutson

Editor

Follow this and additional works at: https://digitalcommons.unl.edu/zeabook

Part of the African American Studies Commons, Modern Literature Commons, Nonfiction Commons, Other Feminist, Gender, and Sexuality Studies Commons, Other French and Francophone Language and Literature Commons, United States History Commons, and the Urban Studies and Planning Commons

\section{Recommended Citation}

Hearn, Lafcadio and Hutson, Charles Woodward, "Creole Sketches" (2022). Zea E-Books Collection. 114. https://digitalcommons.unl.edu/zeabook/114

This Book is brought to you for free and open access by the Zea E-Books at DigitalCommons@University of Nebraska - Lincoln. It has been accepted for inclusion in Zea E-Books Collection by an authorized administrator of DigitalCommons@University of Nebraska - Lincoln. 

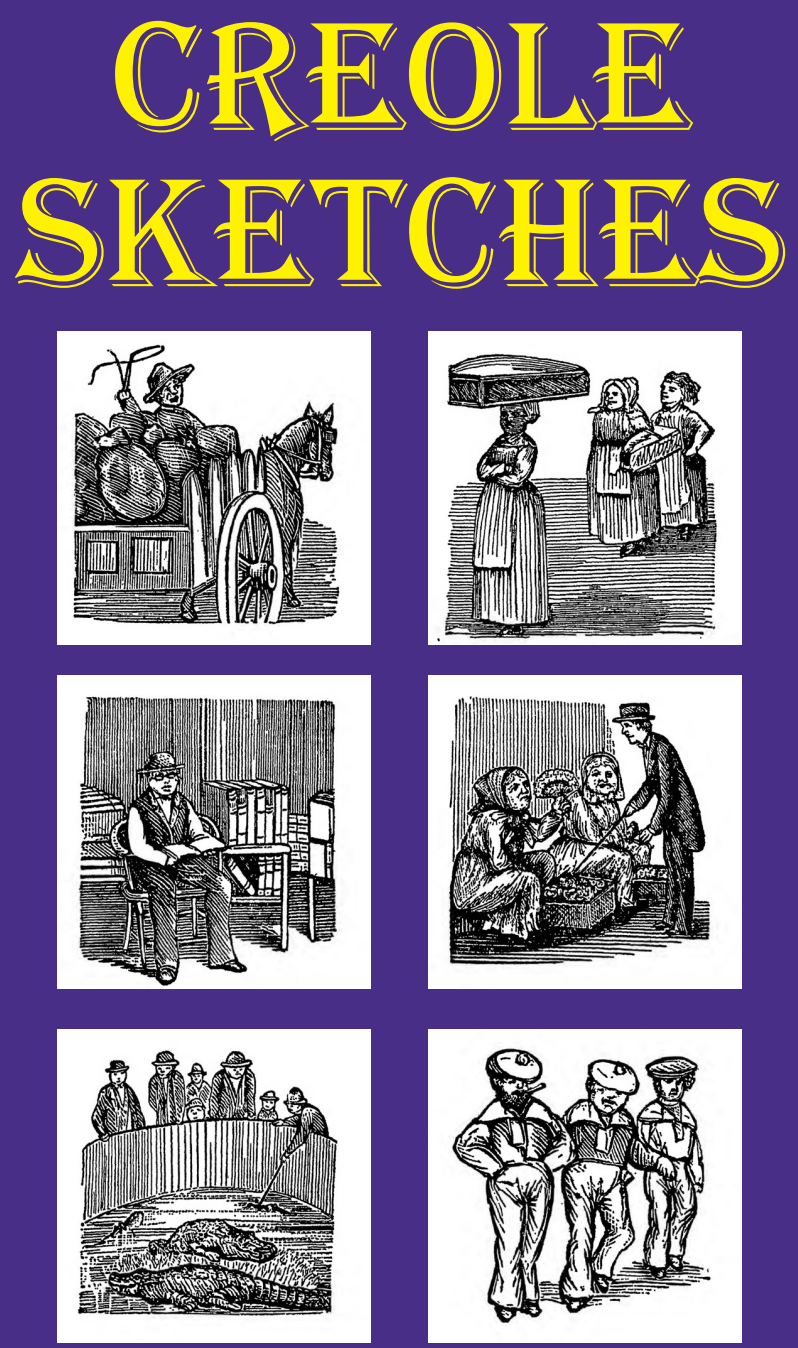

Lafcadio Hearn 


\section{With Illustrations by the Author}

New Orleans in 1878 was the most exotic and cosmopolitan city in North America. An international port, with more than 200,000 inhabitants, it was open to French, Spanish, Mexican, South American, and West Indian cultural influences, and home to a thriving population descended from free African Americans. It was also a battleground in the fight against yellow fever (malaria) and in the political upheavals that followed the end of Reconstruction. The continued influx of Anglo-Americans and the renewed ascendancy of white supremacists threatened to overwhelm the local blend of languages, races, and cultures that enlivened the unique Creole character of the city. Writing for an English-language newspaper, Lafcadio Hearn presented the speech, charm, and humor of the Creolized natives on the other side of Canal Street, and illustrated his sketches with woodcut cartoons - the first of their kind in any Southern paper. These vignettes, published in the New Orleans Daily Item during 1878-1880, capture a traditionalist urban world and its colorful characters with a delicate and sympathetic understanding.

ISBN 978-1-60962-224-4

doi: 10.32873/unl.dc.zea.1312

Zea Books

Lincoln, Nebraska

\section{Nebraska




\section{C $_{\text {reole }} \mathbf{S}_{\text {Ketches }}$}

by

\section{Lafcadio Hearn}

Edited by Charles Woodward Hutson

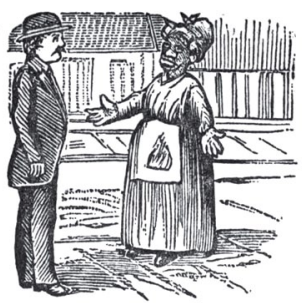

\section{With Illustrations by the Author}

Zea Books

Lincoln, Nebraska

2022 
Copyright, 1922 and 1924, by Houghton Mifflin Company; now in the public domain.

ISBN 978-1-60962-223-7 paperback ISBN 978-1-60962-224-4 ebook doi: 10.32873/unl.dc.zea.1312

Zea Books are published by the University of Nebraska-Lincoln Libraries.

Electronic (pdf) edition available online at https://digitalcommons.unl.edu/zeabook/

Print edition available from Lulu.com at http://www.lulu.com/spotlight/unllib

University of Nebraska-Lincoln does not discriminate based upon any protected status. Please go to http://www.unl.edu/equity/notice-nondiscrimination

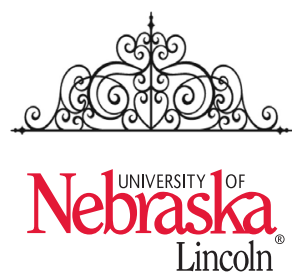




\section{Contents}

Introduction . . . . . . . . . . . . . 5

Lafcadio Hearn's Cartoons . . . . . . . . . . . . . 9

The Glamour of New Orleans

(November 26, 1878) $\ldots \ldots \ldots \ldots$

La Douane (December 2, 1878) . . . . . . . . 18

Morning Calls - Very Early (July 7, 1880) . . . . . . 21

The City of Dreams (March 9, 1879) . . . . . . . . . 23

Ultra-Canal (July 17, 1880) . . . . . . . . . . . 27

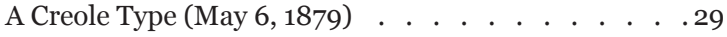

Ghosteses (August 18, 1880) . . . . . . . . . . . 34

A Visit to New Orleans (May 10, 1879) . . . . . . . 37

Quack! Quack! (August 20, 1880) . . . . . . . . . 41

Complaint of Creole Boarding-House-Keeper

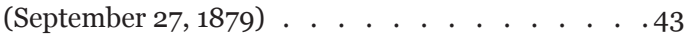

The Boarder's Reply (September 28, 1879) . . . . .46

Coming Events Cast Their Shadows Before

(August 19, 1880) . . . . . . . . . . . . . . . . . 49

Why Crabs Are Boiled Alive (October 5, 1879) . . . . 50

A Creole Journal (October 5, 1879). . . . . . . . . . 51

The Restless Boarder (October 27, 1879) . . . . . . 53

Furnished Rooms (November 2, 1879) . . . . . . . 55

Char-Coal (August 25, 1880) ․ . . . . . . . . . 57

Mexican Coins (November 3, 1879) $\quad \ldots \quad \ldots$

Louisiana People Not Gay (November 4, 1879) . . 62 A Creole Courtyard (November 11,1879 $\ldots \ldots$. . . . 63

The Creole Character (November 13, 1879) $\ldots$. . . 65 
Des Perches (August 30, 1880) . . . . . . . . . . . 67 A Kentucky Colonel Renting Rooms

(November 15, 1879) . . . . . . . . . . . . . . . .69

The Dawn of the Carnival (February 2, 1880) . . . . . 70 A Mexican's Gratitude (April 12, 1880) . . . . . . . . 72 Washerwomen (August 31, 1880) . . . . . . . . . . 75 Attention! Azim! (July 8, 1880) . . . . . . . . . . . 78 An Ultra-Canal Talk (July 13, 1880) . . . . . . . . . 81 Sons of the Sea (September 1, 1880) . . . . . . . . . 84 A Creole Song (July 26, 1880) . . . . . . . . . . . . . 87 The Grandissimes (September 27, 1880) . . . . . . . . 89 The Indignant Dead (September 8, 1880) . . . . . . .93 A Creole Mystery (October 6, 1880) . . . . . . . . . . 95 Whited Sepulchres (September 9, 1880) . . . . . . .99 Eleusis (November 12, 1880) . . . . . . . . . . . 101 Latin and Anglo-Saxon (November 24, 1880) . . . . 105 The Flower-Sellers (September 11, 1880) . . . . . . 108 A Visitor (November 26, 1880) . . . . . . . . . . 110 Creole Servant Girls (December 20, 1880) . . . . . 114 The Alligators (September 13, 1880) . . . . . . . . 117 Home (January 8, 1881) . . . . . . . . . . . . . 119 Old-Fashioned Houses (January 12, 1881) . . . . . 124 The Vendor of Wisdom (September 15, 1880) . . . . 128 Some Positive Opinions (April 27, 1881) . . . . . . 131 Voices of Dawn (July 22, 1881) . . . . . . . . . . 136 


\section{INTRODUCTION}

Until the publication of his "Fantastics and Other Fancies" the work done by Lafcadio Hearn for the Item was utterly unknown. But those weird or dreamy sketches constituted but a small part of his work on that little journal. As assistant editor during the earlier years of his stay in New Orleans, he produced an immense number of editorials, translations, book reviews, dramatic criticisms, and sketches of all sorts, writing as he did for the paper every day, and not merely on Sundays, as was for the most part his custom in the case of his work with the Times-Democrat in the later years of his sojourn in this city.

The present volume contains a selection from his "Creole Sketches," together with a few other fanciful papers in a similar vein.

Partly because he was always deeply immersed in work or in study, partly on account of his natural shyness, he led in New Orleans the life of a recluse. Yet he had some friends, whom he greatly valued, and who still speak warmly of their intercourse with him. In one of his letters to Basil Hall Chamberlain, many years afterwards, he speaks of Charles Gayarré, the historian, as a "charming friend" of his. And in another letter to Chamberlain, in his remarks on modern Provençal, he says, "Some of my New Orleans friends used to speak it well." George W. Cable, the novelist, whose works he reviewed in the Item with enthusiastic praise, says that Hearn was a frequent visitor at his house, and that they profited by mutual frank criticism of each other's writings. Dr. Rudolph 
Matas, the renowned surgeon, tells of intimate companionship with him during his stay in this city. Dr. Lucien Salomon, a physician of long-established reputation, states that he was introduced to him by Dr. Matas, and that, despite his eccentricities, he found him a "lovable fellow." We know that Hearn's lifelong friendship with Miss Elizabeth Bisland, now Mrs. C. W. Wetmore, began when they were workers together in the office of the Times-Democrat. During these later years, too, he was befriended by the Bakers, both Page and Marion, and the wife of the latter, known to literature as Julia K. Wetherell. He had friends, too, who were not so intellectual, but for whom his affection was great. One of these was Mrs. Courtney, his landlady through the later years of his sojourn in this city, to whom he wrote from time to time, during temporary absences, letters that prove how much he valued her kindness, and with whom he left that notebook which enables us largely to supplement his bibliography, hitherto confined to the lists set down in Dr. Gould's book.

It is true that many of these friendships date from a period subsequent to his connection with the Item. But during those earlier years he resided wholly in the Creole quarter of the city, and there he had large opportunities for studying Creole character and Creole customs. At this time Colonel John W. Fairfax, then owner of the Item, was, with the exception of George W. Cable, perhaps his only friend in the city. But he evidently soon made other friends, and those chiefly among persons more familiar with the Creole, than with the American, side of the city. 
There are many marks by which his unsigned articles can be identified, among which not the least striking are certain peculiarities in punctuation. But the most noteworthy of all is the higher note, sometimes philosophic, sometimes romantic, to which he soars in every paper, whatever the subject. With him the touch artistic is always there: Journalism becomes Literature.

It should be noted, as a curious addendum to "La Douane," that the niches of the New Orleans Custom House are still empty of the figures that were destined in the original design to fill them. Can it be that they are still hidden away in some locked, and perhaps forgotten, room of that vast building?

"Eleusis" is an exquisite trifle, an accurate and detailed description of the toilet and dress of the ballet dancer, a fit companion-piece to "Les Coulisses" as an evidence of his intimacy with the inner secrets of the stage during his service as dramatic critic; - French in its lightness of touch, and dainty as the apparel of which it treats.

In "Some Positive Opinions" we have another and very different token of his experience when accorded the freedom of the greenroom.

The review of "The Grandissimes" - it is only one of several - is included as holding a close relationship with the sketches that are professedly Creole.

"The City of Dreams" depicts the result of the fateful yellow-fever epidemic of 1878 upon the smitten souls of the people. Fortunately science has forever rendered impossible the return of that heavy weight of woe that hung over the city in the year of which this 
and many others of Hearn's more poignant sketches are memorials.

The Cartoons, done by his own hand, of which a few have been introduced, have been placed out of their chronological order for the purpose of distributing them through the book.

They were found in the Item files for 1880 , and our suspicion that they, with the verses and, brief paragraphs accompanying them, were Hearn's was confirmed by a statement from Colonel Fairfax made to my daughter, Ethel Hutson, in 1913, and since corroborated by him. I append her account of his statements.

Charles Woodward Hutson 


\section{LAFCADIO HEARN'S CARTOONS}

Lafcadio Hearn's first employer in New Orleans is still living - an active old gentleman of eighty-two, who may be found at his desk in the bank any day during business hours. He is Colonel John W. Fairfax, a veteran of the Confederate army, having gone into the war at the age of twenty; and he was a newspaperman of the sixties and seventies.

He was the owner of the Daily City Item when that paper gave Hearn his first employment in the city to which he came so enthusiastically in the winter of 1877-78, and where he so nearly starved before he got that job, in the summer of 1878 .

"I remember Hearn very well, indeed," says Colonel Fairfax, "even that first day when he came to us for work. I am not sure whether he came to me in my office on Gravier Street, or whether Bigney - Mark F. Bigney, then managing editor of the Item - sent for me to come and see if we wanted to take him on.

"You see, Hearn was a most unprepossessing object at first sight. That odd rolling eye of his was the only thing you could see at first - enormous, protruding. After you got used to that eye, you saw that his other features were very good, and his face refined. But in addition, when he first presented himself here he was miserably dressed, and even his hands were grimy and his nails black.

"He had had a hard time, you see, since he had come down from Cincinnati; and one reason why Bigney hesitated about taking him on was that we had 
heard that he had had to leave Memphis on account of his violent Republican ideas. Perhaps I oughtn't to tell that even now - but surely the war is over by this time. In those days, however, it was a serious thing in this part of the world, and it worked against Hearn.

"We took him on, though, and I had such a sort of sympathy for the poor fellow, who looked as if he hadn't had a good meal in months, and who seemed to feel keenly the way the boys treated him, on account of his Republican ideas, and his queer appearance and all that, that I asked him to come up to our house to dinner - not once, but again and again - twice a week, for a good while.

"Just the other day, my wife was recalling the time he first came. Dressed in a blue coat, linen trousers, his coat buttoned up to the throat to hide his shirt 'wasn't he an odd sight?' said my wife. And shy? Why, that first meal he just sat and crumbled his bread would scarcely eat a mouthful. Ours was a big family, and there were almost always guests; and until he got over his shyness we used almost to ignore him, going on with the family routine as if he were not there, to avoid embarrassing him.

"But when he got over that shyness, he was a charming talker; and we grew attached to him. My daughter used to tease him.

"He wrote editorials for the Item, but most of the political editorials were written by Bigney or by me. When, in the winter of 1881, the Times-Democrat offered him a place on its staff, we had to let him go, because we could not meet the offer. The Item then was only a two-page sheet." 
Besides these editorials, and the occasional "Fantastics" which Hearn contributed to the Item between the summer of 1878 and the winter of 1881 , a column of book reviews, called "Our Book Table," and a column of advice to young people, somewhat on the order of those of "Ruth Ashmore," "Dorothy Dix," and "Beatrice Fairfax," were conducted for many months by the pen which afterward wrote " Chita"! No wonder Hearn hated journalism.

Strangest of all, the young Irishman who was finding his metier through so many incongruous and distasteful tasks, drew a series of cartoons which appeared daily for more than half a year. They are quaint, grotesque, and crude, but many of them show the same weird suggestiveness to be seen in the odd little sketches with which he illustrated his letters to certain friends, and, like these, remind one of the drawings of Victor Hugo and of that artist whom Hearn so greatly admired, Gustave Doré.

Colonel Fairfax is authority for Hearn's authorship of these cartoons and the verses or prose sketches which accompanied them. In reply to queries about the articles to be ascribed to his queer protégé, the former owner of the Item said: "Hearn did not write the 'Wayside Notes' - that was my column. But I'll tell you what he did write - those verses illustrated with woodcuts. They were all Hearn's - his ideas, his verses, his drawings. He drew those cartoons the first newspaper cartoons in this part of the country - and he cut them with his penknife on woodblocks - on the backs of old wooden types, which had been used for advertisements. They were just the 
right height, you see, to fit into the bed - we used the old-fashioned flat-bed press, of course - and every day he would whittle out one of those drawings. Some of them were right interesting, too. You remember those about the old 'Magazine Market gang'? That was a gang of hoodlums that ruled all that part of the city, and the police were powerless. Hearn held them up to ridicule, in these cartoons - the hoodlums and the police - till something had to be done, and the police finally took hold and broke up the gang."

Many of the cartoons were political, a few on phases of national politics, for a Presidential campaign was at its height during the summer and fall of 1880 , when this series appeared. Some were about the follies of the municipal officials, especially the Board of Health, whose futile efforts to control the yellow fever and other epidemics were bitterly attacked by the Item in those days.

But the majority of the cuts pictured quaint local customs, or else certain foibles of human nature which have neither season nor place. A dozen or so were devoted to the delineation of special public nuisances, under the head of "Illustrated Letters from the People," and anathematized the churl, the bore, the boy on "The Unspeakable Velocipede," and others whom the letter-writers objected to, as hostile to civic welfare or private comfort.

Some of these "letters" may have been contributed, though the drawings which illustrated them were Hearn's. Others must have been written by Hearn himself, for they are in his most extravagant style. 
Colonel Fairfax says that it is possible some of the drawings may have been made by others, but he has no recollection of any one else but Hearn doing this: and he does remember him very distinctly, at work "with a penknife that had two blades, using first the large one and then the small one, to get the effect he wanted on the block."

The woodcuts we have chosen, out of the nearly two hundred which appeared between May 24 and December 10, 1880, have been selected because they illustrate the Creole life which fascinated Hearn in all its features - the "ultra-Canal" life which he ever preferred to the conventional uptown Americanized districts; the humble life of landladies and booksellers, of washerwomen and darkies selling clothes-poles; of queer old men haunted by "ghosteses," of flowersellers and cemeteries, quacks and hoodlums.

ETHEL HutSON

New Orleans

October 27, 1923 



\title{
CREOLE SKETCHES
}

* $*$

*

\section{The Glamour of New Orleans}

\author{
Item, November 26, 1878
}

The season has come at last when strangers may visit us without fear, and experience with unalloyed pleasure the first delicious impression of the most beautiful and picturesque old city in North America. For in this season is the glamour of New Orleans strongest upon those whom she attracts to her from less hospitable climates, and fascinates by her nights of magical moonlight, and her days of dreamy languors and perfumes. There are few who can visit her for the first time without delight; and few who can ever leave her without regret; and none who can forget her strange charm when they have once felt its influence. To a native of the bleaker Northern clime - if he have any poetical sense of the beautiful in nature, any love of bright verdure and luxuriance of landscape - the approach to the city by river must be in itself something indescribably pleasant. The white steamer gliding through an unfamiliar world of blue and green - blue above and blue below, with a long strip of low green land alone to break the ethereal azure; the waving cane; the ever-green fringe of groves weird with moss; the tepid breezes and golden sunlight - all deepening in their charm as the city is neared, make the voyage 
seem beautiful as though one were sailing to some faroff glimmering Eden, into the garden of Paradise itself. And then, the first impression of the old Creole city slumbering under the glorious sun; of its quaint houses; its shaded streets; its suggestions of a hundred years ago; its contrasts of agreeable color; its streets reechoing the tongues of many nations; its general look of somnolent contentment; its verdant antiquity; its venerable memorials and monuments; its eccentricities of architecture; its tropical gardens; its picturesque surprises; its warm atmosphere, drowsy perhaps with the perfume of orange flowers, and thrilled with the fantastic music of mocking-birds - cannot ever be wholly forgotten. For a hundred years and more has New Orleans been drawing hither wandering souls from all the ends of the earth. The natives of India and of Japan have walked upon her pavements; Chinese and swarthy natives of Manila; children of the Antilles and of South America; subjects of the Sultan and sailors of the Ionian Sea have sought homes here. All civilized nations have sent wandering children hither. All cities of the North, East, and West have yielded up some restless souls to the far-off Southern city, whose spell is so mystic, so sweet, so universal. And to these wondering and wandering ones, this sleepy, beautiful, quaint old city murmurs: "Rest with me. I am old; but thou hast never met with a younger more beautiful than I. I dwell in eternal summer; I dream in perennial sunshine; I sleep in magical moonlight. My streets are flecked with strange sharp shadows; and sometimes also the Shadow of Death falleth upon them; but if thou wilt not fear, thou art safe. My charms are not the 
charms of much gold and great riches; but thou mayst feel with me such hope and content as thou hast never felt before. I offer thee eternal summer, and a sky divinely blue; sweet breezes and sweet perfumes, bright fruits, and flowers fairer than the rainbow. Rest with me. For if thou leavest me, thou must forever remember me with regret." And assuredly those who wander from her may never cease to behold her in their dreams - quaint, beautiful, and sunny as of old - and to feel at long intervals the return of the first charm - the first delicious fascination of the fairest city of the South. 


\section{La Douane}

Item, December 2, 1878

That vast gray building on Canal Street, which seemeth ancient as Karnac, and upon which princely sums have vainly been expended in the foolish hope of completing it, has long troubled us with a strange impression difficult to analyze. A sense of weight and antiquity oppresses the beholder when he gazes upon it. Kinglake's nightmare of "solid immensity" may be realized by a careful study of it; and its loftiest portion affords an artistic effect of ruin - not the picturesque ruin of feudal remains, but ruin as of Egypt, vast and shadowy and dusty. It has been to the United States Treasury what the sieve was to the daughters of Danaüs. Rivers of gold have been poured into it; yet it remaineth as before. Its marble hall seems like the Pharaonic burial-chamber in the heart of the granite monument of Cheops; and its doors exhale in the most arid and burning weather a breath of damp chilliness, such as smites a mourner in the face when he opens the iron gates of a family vault. So weirdly does it seem to hint of Death and the Past that one cannot help wondering why its corridors are not hypogea and its offices filled with mummies. Without, in sooth, its very shape is ominous. It is, despite its windows and entrances, its pilasters and niches, a huge sarcophagus of granite. Its form is funereal; and against the dismal immensity of its exterior, the openings in its awful walls seem but as carvings upon some ancient stone coffin. 
It is in very truth a sarcophagus, wherein repose the mummified remains of that which was once mighty, but not magnanimous; of that which was once rich, yet not honest; of that which once believed itself eternal and invulnerable, yet which expired like Herod of self-engendered corruption. Its corridors are indeed hypogea, filled with the mummies of Radical Pharaohs; and its marble hall a burial-chamber, empty, indeed, like that in the stony heart of the Great Pyramid, yet haunted by the ghost of that regime for which none are left to mourn.

But those empty niches in the great waste surfaces of the quadruple facade! Ah, those niches! those niches! Why are they accursed with emptiness; why made hideous with vacuity? The statues of stone created to fill them were chiseled out a quarter of a century ago; and yet never have beheld the light of day. Their stone eyes have never gazed upon the glory of Canal Street; their marble ears have never hearkened to the gossip of politicians; their rigid forms have never left the enclosure of the wooden coffins into which they were first packed for importation. They sleep in the awful silence and darkness of the most dismal chamber in the whole gray building. They sleep, and the dust thickens upon their faces; and sometimes in the dead waste and middle of the night they do converse dismally together. They represent Faiths not worshiped under the old regime, Hopes that had failed, and Charities that would have been scorned; Virtues that had fled, or had hidden themselves in lonesome places; Saintly 
Personages* who could not in those days have received respect; and Great Statesmen, perhaps, whose marble faces would have blushed into Egyptian granite, could they have seen that which was, but will never be again. And Radicalism, therefore, hid them away - not, indeed, out of consideration for their feelings, but out of consideration for its own. For it could not have endured the silent reproach of those eyes of marble, or dare to concoct plots within the reach of those ears of marble; and therefore the Faiths and the Virtues were cunningly hidden away where their presence could offend nobody. And now they ask, "When shall we be delivered from darkness and silence and oblivion? When shall the trumpet sound for our resurrection day? When shall we behold the great glory of the Southern sun and the splendor of Canal Street? Better even with broken noses to stand on our pedestals, better even to lose several of our Carrara limbs than this." But the silence and the darkness and the dampness remain; and echo answereth nothing.

* We might be mistaken, perhaps, in regard to the symbolic character of some of the Custom-House statues; for no living man of this generation hath a memory sufficiently strong to remember the day of their coming or the description which accompanied them. 


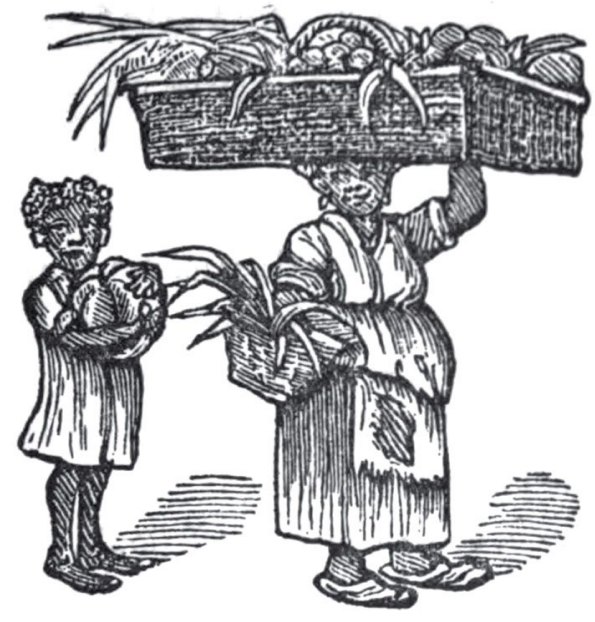

\title{
Morning Calls - Very Early
}

\author{
Item, July 7, 1880
}

Pitis sans papa, pitis sans maman!

Qui ça ou z'aut' fé pou' gagnin l'arzan!

N'a couri l'aut'bord, pou' cerce pat sat, N'a tournein bayou pou'pece patassa,

Et v'la comme ça n'a té pou' l'arzan.

Pitis sans papa, pitis sans maman,

Qui ça ou z'aut' fé pou' gagnin l'arzan!

N'a couri dans bois fouille latanie,

N'a ven so racin pou' fourbe planche,

Et v'la comme ça n'a te fé pou' l'arzan. 
Pitis sans papa, pitis sans maman,

Qui ça vous z'aut' fé pou' gagnin l'arzan!

Pou' fé di té n'a fouille sassafras,

Pou' fe li l'encr' n'a porte grain salgras (chou-gras),

Et v'la comme ça ne te fé pou' l'arzan.

Pitis sans papa, pitis sans maman, Qui ça ou z'aut' fé pou' gagnin l'arzan!

N'a couri dans bois ramasse caucos, Avé non la caze n'a trapé zozos,

Et v'la comme ça n'a te fé pou' l'arzan.

Pitis sans papa, pitis sans maman, Qui ça ou z'aut' fé pou' gagnin l'arzan! N’a couri a soir chez Mamzell Maroto, Dans la rie Ste Anne, ça n'a té sous leto, Et v'la comme ça n'a te fé pou' l'arzan.

The above ancient Creole ditty contains some curious information about the occupations which some of our old-fashioned colored Creoles alone follow, and of which they alone know the Secrets. We are indebted therefor to a gentleman of this city who has made a rich collection of these songs. 


\section{The City of Dreams}

Item, March 9,1879

Latterly it has been said that if New Orleans has any special mania which distinguishes it from other cities, it is the mania of "talking to one's self." It were useless to deny so widely recognized a fact as the propensity of people in New Orleans to perambulate their native streets conversing only with themselves. And strangers visiting us have said: "The people of New Orleans are inclined to madness; they converse continually with themselves, which is a sign of insanity." Is it that the people are being driven mad by stupid legislation and business losses and outrageous taxes? God only knows! But they do talk either to themselves or to viewless beings or to the sleepy shadows that fling jagged bits of darkness across the streets on sunny days.

They are comparatively many, these lovers of solitary musing; and usually seek the quiet of the most deserted streets - those streets to which the Secret Police of the East give the ominous name of dead streets. Perhaps one might say as well, streets of the dead.

At one time we took a special interest in watching those wandering and murmuring spirits. They are of various ages; but most generally advanced in years. The action of the younger men or women is usually quick and nervous; that of the older, slow and meditative. The former often speak angrily as if brooding over some wrong; the latter, rather in sorrow than in anger. All of which is quite natural and to be expected from those who talk to themselves. 
What do they talk about?

That is a matter not always easy to find out. The hard echo of a brisk footstep on the pavement, even the sudden fluttering of a leafy shadow, seems often sufficient to break the reverie; the speaker looks about him like one awakened from a dream, gazes with a half-timid kind of suspicion at those who pass by, as if fearing to have been overheard; and walks off at a quicker gait. To study the character of these people perfectly, one must wear rubber shoes.

It would be cruel to wear india-rubber shoes for such a purpose; it would also be despicable. Therefore we cannot fully answer the question -

What are they talking about?

But occasionally the most innocent passer-by cannot fail to catch a word or two - sometimes strangely full of meaning, sometimes meaningless. We have heard such words. Occasionally vast sums of money were mentioned - billions, quintillions! - a sure sign that the speaker was financially stripped, and had little hope of favors from the goddess Fortuna. Sometimes we heard odd curses - men cursing themselves, and others, nameless places and nameless people, unknown memories and unknown misfortunes. Sometimes they spoke cheerfully, and laughed to themselves softly; - but this was seldom, very, very seldom.

Before the epidemic we fancied that the majority of these conversations with airy nothings were upon the subject of money. Indeed, most of the fragmentary mutterings which reached us seemed related to dreams of wealth - wild, vague, and fantastic - such dreams as are dreamed by those who have lost all and 
hope for nothing, but who seek consolation in the splendor of dreams of the Impossible.

Then came the burning summer with its burning scourges of fever; - under the raw, merciless, dizzy sunlight, and the pitilessly clear infinite of warm blue above, the mutterers still wandered the silent streets, seeking out the bits of shadow, as Arabs oases in a world of yellow sand; - and they talked more than ever to themselves and to the shadows, to the vast void above and to the whispering trees that drooped in the mighty heat.

So the months rolled dryly and fiercely by; the sun rose each day with the same glory of angry heat; and the sky glowed each evening with the glare of molten brass. And the talkers became fewer; but they seemed to talk much more than they ever had before done. They talked to the black streamers that fluttered weirdly at the handles of muffled bells, and to ghostly white things hung to cottage doors and to the long processions that rumbled ominously toward the Places of Tombs.

Sometimes it seemed that one heard a sound of sobbing - stifled sobbing; as if a man were swallowing a bitter grief with bitter determination - but this was perhaps imaginary; for there were so many strange sounds in that strange summer that no one could well trust his ears.

The summer waned; and yet it seemed at last as though the number of those who talked to invisible things became greater. They did become greater in number. There was no doubt of it remaining before the first cold wind came from the far North, boisterous 
and wild as though suddenly freed from some Arctic enchanter. And the numbers of the mysterious ones waxed greater.

Then at intervals their words fell upon our ears; and it seemed that the character of them had undergone a change - no longer expressing ideas of wealth. They had ceased to speak in our hearing of money. They spoke of the dead - and muttered remembered words uttered by other tongues - and asked information from waving shadows and white walls regarding people that God only knows anything about.

Perhaps they remembered that the only witnesses of some last interview were the same white walls and waving shadows. And the shadows lay there at just the same angle - well, perhaps, the angle was a little sharper - and they were waving just as dreamily as then. And perhaps a time might come in which all Shadows that have been must answer all questions put to them.

Seeing and hearing these things, we somehow ceased to marvel that some people dwelling in the city of New Orleans should speak mysteriously and hold audible converse with their own thoughts; forasmuch as we, also, dreaming among the shadows, spoke aloud to our own hearts, until awakened by an echo of unanswered words. 


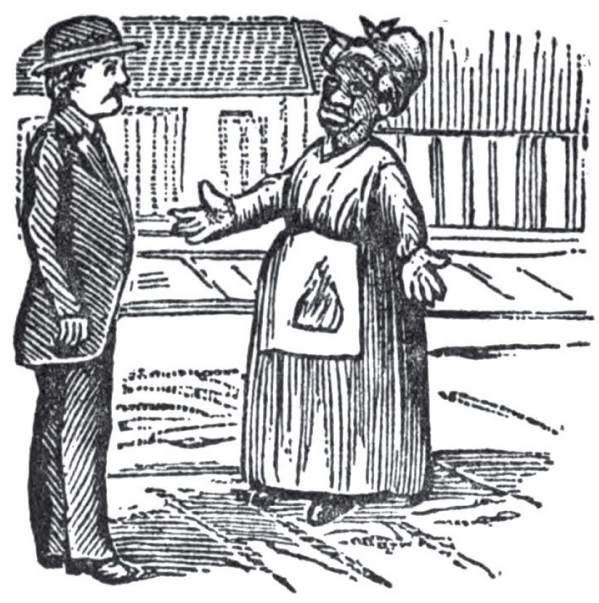

\section{ULTRA-CANAL}

Item, July 17, 1880

"Is the old man in?"

"Ah! de ole man! He not been live here since more as tree year. He have lef all his furnizer here; but I not know vat him become. I tink vat he lose himself."

"Lose himself?"

"Yes, I tink he lose to himself. Monsieur not speak Français? No? Eh bien I make try you explain, zough I not good English speak.

"You see, he have to him ze brain attack, I zink, of recent. He lose vat to him belong. Some time he lose coat, some time pant, some time shirt,- all time nightkey. I vas oblige for him order more as tirteen nightkey, for vat I make him to pay. He live in one kind of dream - il s'embêtait - he embeast himself much 
- he seem all day like vat you call sonambule."

"Yes, yes! well?"

"Eh bien! - some time he put on tree pair pant. Some time on hot day he put him on ze overcoat. One day I see him try to put on to him ze pant for ze shirt. He have put to him ze arm in ze leg of ze pant; an' he swear sacre roucht for dat he not could put on -"

"Yes, I understand. But what has become of him?"

"Attendez un peu. I tell one. One oder day he not have any clothes on, an' he try to find his key, an' he swear at tailor for sacre charogne for dat he not have made him pocket vat he can easy find. He forget vat he not be dress. Den he lose to him money all time vat make him angry much. One time he take by mistake coat vat not to him belong, and take it to tailor for dat he put tail to it; an' he has to pay to de oder man, of wich he spoil de coat."

"Yes. But where is -"

"Vait - I explain you. He lose everyting - handchef, towl, pockbook, monee, key - all time. One domestique he employ only for find vat he los'; and domestique run himself away, for dat he not more can so hard work endure."

"But, for God's sake, what has become of him?"

"Monsieur, I not can you tell. He go out one morning, and I not have hear or see of him after. His furniser an' all be in my house. He have pay of advance. He owe me notings. He have not ever come back. No one have see or hear. I be satisfy vat himself he lose - like as he lose every oder ting - vat he lose never more find. Veil, he lose to himself. He never more himself find. Que voulez-vous?” 


\title{
A Creole Type
}

\author{
Item, May 6, 1879.
}

It is a little curious how the old Creole element preserves its ancient customs and manners in the very heart of the changes that are going on about it. At halfpast nine or ten o'clock the American city is all alive a blaze of gas and a whirl of pleasure. The old French town is asleep; the streets are deserted; and the shadow of a pedestrian makes a moving black speck against the moonlight on the pavement only at long intervals. Creoledom wakes up as slowly and cautiously as possible; and has not fairly begun to enter upon the business of the day until the sun has warmed the streets. The comparatively new generation of American citizens, when brought into contact with this older population, is utterly unable to understand the difference of character; and shuns as much as possible the transaction of business with it - which contents the Creoles perfectly well. They seem to tolerate those who understand them, and to abominate those who do not, and propose to live in the good old way as long as possible - marrying and giving in marriage, aiding one another in a good brotherly way, and keeping themselves to themselves. If there is one virtue they possess remarkably, it is the virtue of minding their own affairs - which, alas! cannot always be said of all other people who dwell in New Orleans.

Nothing, perhaps, can be funnier than the contrast of character brought out by the attempt of a stiff-mannered stranger to do business with a typical Creole, 
especially if the latter be of the fair sex. Let us imagine, for example, the episode of renting a house to a foreigner - somebody whom chance or curiosity has prompted to seek quarters in the old-fashioned part of the city. The stranger is a little phlegmatic; the woman is as much the opposite as any human being could well be - a little dark, tropically dark, but quite attractive, with magnetic eyes, an electric tongue, and an utter indifference to those ordinary feelings which prompt landladies to play the agreeable; - proud as a queen, and quite as determined to show her own individuality as the stranger is to conceal his own. She has a nice little house; and the stranger would like to rent it. She would also like to rent it; but only according to her own original idea of conditions, and she would never think of concealing her inmost feelings on the subject. She is determined that nobody shall impose upon her, and that fact she proposes to explain very forcibly forthwith; the stranger appears to be a good sort of man, but appearances are so deceitful in this wicked world!

She - "Ah, yes, monsieur, I have a nice little house. Let me beg of you to wait a moment until I open the other door, so that you can enter my parlor."

$\mathrm{He}$ - "But what is the rent of the house?"

She (in a voice sweeter than the sweetest honey) - "One minute! - this way, monsieur - come in; be seated, if you please."

$\mathrm{He}$ - "But what is the rent of - "

She (shutting the door, and placing herself before it like a statue of animated bronze, and suddenly changing the sweet voice for a deep and extraordinarily 
vibrant alto) - "Ah, now, monsieur, let us at once understand one another. I have a nice little house. Good! You want a nice little house. Good! Let us understand one another. In the first place, I do not rent my house to everybody, monsieur. Oh, no, no, No!!" (crescendo).

$\mathrm{He}-$ " But what is the rent of -"

She (imperiously, terrifying him into silence with a flash of her black eyes) - "Do not interrupt me, monsieur. Three things I require from a tenant. Do you know what the first is? No? - then I will tell you. Cash, Cash, CAsH! (crescendo) - right here in my hand - in advance - ah, yes, all the time in advance."

$\mathrm{He}$ (very timidly) - "Yes, certainly - I know - of course! - I expected; - but what is -"

She (in a voice like the deepest tone of a passionately agitated harp) - "Attends, donc, monsieur. The second thing which I require from a tenant is a guarantee that he will stay. Ah, yes! I am not one of those who rent houses for a week, or a month, or six months. Mon Dieu, non! I must have people who STAY, STAY, STAY (pianissimo); and they must stay a long, long time. You must not come to me if you want a house only for -"

$\mathrm{He}$ (with a last and desperate effort, which happens to be partially successful) - "O madam, I want to stay for a number of years in the house, if I take it; but I cannot take it until I have seen it."

She - "You shall see it, monsieur, you shall see it (parenthetically). Now the third thing which I require from a tenant is absolute cleanliness, absolute, absolute! No spitting on the walls, no dirt upon the doors, no grease upon the planking, no cochonnerie in the 
yard. You understand me, monsieur? Yes! - you shall see the house: these are the keys."

$\mathrm{He}$ - "But what is the rent of -"

She (frightening him into motionlessness by a sudden gypsy-like gesture) - "Ah, monsieur, but I cannot trust you with these keys. No; my servant shall go with you. I cannot have all the doors of my house left open. No; I have had too much experience. My servant shall go with you. She shall bring me back my keys. Marie! come here! Go, monsieur, see the house!"

$\mathrm{He}$ (resignedly) - "Thanks, but may I ask what is -“

She (with a superb gesture of withering disgust and another of terrible determination) - "Do you not know, sir, that I would rather shut the house up until the last day of the world than rent it to the canaille! Ah! the canaille! Monsieur! Ah! the canaille, the canaille!"

(These last words, with an inexpressible look of horror upon her face, which would make the stranger laugh if he were not afraid to laugh.)

$\mathrm{He}$-"And the rent is -"

She (sweetly as a rose-fed nightingale) - "Twentyfive dollars to a responsible party, monsieur."

The stranger is by this time fairly mesmerized. He has listened to a sermon, heard an oration, received a reproof, watched a most marvelous piece of natural acting by a beautiful woman, and felt his own will and purpose completely crushed out of him by the superior vitality and will-power of this wonderful creature, whose gestures, graceful as a bayadère's, seemed to weave a spell of magnetism about him. He sees the house; pays faithfully in advance; gives proper 
recommendations; and never forgets the three requisites which his landlady taught him as forcibly as though she had burned the words into his brain with a red-hot iron. 


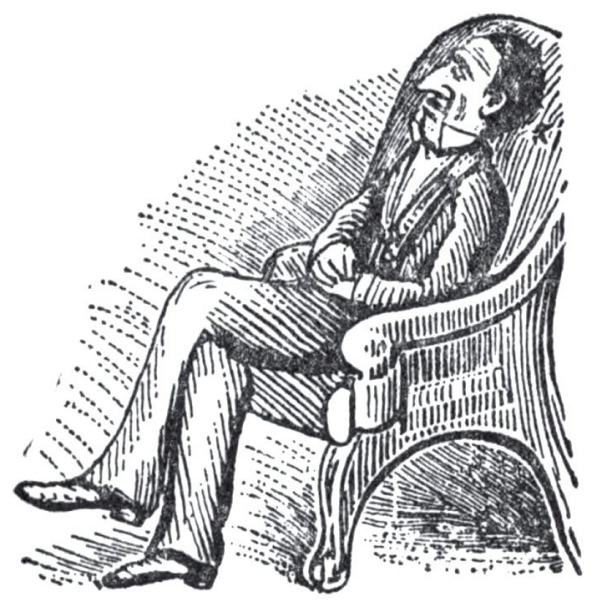

\section{Ghosteses}

Item, August 18, 1880

Midnight in an Ultra-Canal Pension.

You not know vat be dat noise of foots up de stair. Dat be de ole man vat die in my house ago ten year.

I see him now in my t'ought, 'sleep in ze berceuse; afraid to go to his room for cause of vat you call farfadet-goblin and ghosteses.

He vas very, very old, and he see always of tings vat not exist. He be much torment by goblin and ghosteses vat valk all roun' de house in de night; an' he say it vas one curssed house and one curssed city. He tell me dat people dressed like vas dress since one hoondred year come in his room in de middle of de night; 
dat he lock de door but not could dem keep out; dat dey sit silent and make at him face horrible and not speak and not make shadow on de door.

Den he commence to us avake. In de middle of de night he knock at mine door and say, - " Monsieur, mount to my room for dat dere be one man dead in my chamber." So I mount and look and not see no man dead. "He go himself away," say de ole man, "for dat he hear you on stair. But have made stop my clock and my vatch." And I see dat de clock and de vatch not more march, - I not know how.

After dat he often tell me vat dere be in his bed dead vomans; and dat dead beoples him look at trough de vindow. So he become afraid more to bed go, and ven he mount he not himself sleep, but valk all night on de gallery, one lantern in his hand, and shoes all vat be of mos' heavy for drive away ghosteses - ta-ta-tatatatata - all de long of de night. Much also he sing in de night and swear for dat dis be one curssed country of ghosteses. Also he swear at proprietor of house; for dat he not chase ghosteses.

So it arrive at las' dat not person in de house could himself to sleep go, and dat all de vorld begin to demselves much fatigue. Den dey construct one goblin of vatermelon and inside one candle light; and dey it put on stick and one sheet of bed to make look like fantome. So it come to arrive dat ven de ole man march himself he see one goblin march more horrible dan he have before ever see. So he let fall his lantern - vat cost tirteen dollar -, and try to descend stair for me avake for dat I chase him de goblin. But he fall de top to bottom of stair, and make himself much of hurt. 
Never again he not speak and soon he be dead, and no person much sorry himself. But it vas much vicked! It ten year since he be dead; but all de night he march like he march oder time. No one afraid; de ghost of de ole man not make much hurt to personne! 


\title{
A Visit To New OrLeans
}

\author{
Item, May 10, 1879
}

The Devil arrived at New Orleans early yesterday morning, having left his winter residence in Chicago at midnight. There was little need, he thought, to bother himself further about Chicago during the present summer, as he holds a mortgage upon that city, which has at present no prospect of being able to prevent him from foreclosing.

Sensitive to the beauties of Nature, - a trait for which he has ever been famous since that primeval morning when, hiding in the leafy shadows of Paradise, be beheld fair Eve admiring the reflection of her snowy limbs in the crystal waters of Gehon, - the Devil could not suppress a sigh of regret as he gazed with far-reaching eyes along the old-fashioned streets of the city, whose gables were bronzed by the first yellow glow of sunrise. "Ah!" he exclaimed, "is this, indeed, the great City of Pleasure, the Sybaris of America, the fair capital which once seemed to slumber in enchanted sunlight, and to exhale a perfume of luxury even as the palaces of the old Caesars? Her streets are surely green with grass; her palaces are gray with mould; and her glory is departed from her. And perhaps her good old sins have also departed with her glory; for riches are a snare, and gold is a temptation." And the Devil frowned anxiously, and his deep eyes glowed under his brows even as smouldering charcoal glows in the shadows of night. 
The Devil had not been in New Orleans since the period of Reconstruction - a period at which, our readers may remember, it was proverbially said that New Orleans was "going to the Devil." Such also appears to have been the Devil's own personal opinion. He found things in such a condition about that time that he had not been able to find room in his voluminous breast-pockets for all the mortgages which he had obtained upon men's souls; and believing, from the mad career of Radicalism, that the whole city must be made over to him in the course of a few years, he had departed elsewhere in search of employment. "They have no need of me," said the Devil, "in the State of Louisiana."

The history of the overthrow of Radicalism, however, which the Devil read in the Chicago Times, filled him with consternation. He had a gigantic job on his hands in Chicago, and could not just then afford to leave Illinois, for reasons which we have at the present writing no need to specify. But the rumor of a reform in politics in Louisiana, and a just government, pleased him not at all; and he felt exceedingly anxious to visit the Crescent City. It happened, however, that he could not get away until the midnight between the death of Thursday and the birth of Friday. And, moreover, the Devil has private reasons for objecting to travel on Friday.

The odor of the gutters displeased him as he walked down Saint Charles Street, and he stopped his nose with a handkerchief bearing a pattern border of green skeletons and red cupids intertwined upon a saffron ground. "Poverty and dirt are sometimes virtuous," 
said the Devil, as he proceeded on his way. At the next corner he bought all the papers of the previous day. He put the Picayune in his pistol-pocket; cursed the New Orleans Bee and the City Item, and, flinging them back upon the dealer's stand after a brief examination of their contents, he folded up the other papers in a bundle for future reference. "There is too much virtue in the press, I am afraid," said the Devil; "the Picayune is the only paper which suits me."

The police stations were next visited; and the Devil smiled a ghastly smile. "I have no fault to find with the police," he said; "and that reminds me that my own police force below is getting disorganized. I'll have to recruit in New Orleans."

An examination of the records in the Auditor's office tickled him, until he exploded in an abysmal laugh - a series of bass notes singularly like the famous laugh of Mephistopheles in Faust. "Why, this system is almost as good as Radicalism," he said. "Forty-five thousand dollars for running an Auditor's office!"

He next read the order of the Mayor to the colored churches, and nodded his head approvingly. "Good enough in its way," he said.

By twelve o'clock he had visited all the public institutions; - the Sanitary Association highly displeased him; but the Board of Health put him into an uproarious good humor. "I was a fool to come down here at all," he said; " this Board of Health can do my work better than I can do it myself, and the people seem to be just fools enough to let them do it. Instead of honest poverty, I find vicious poverty; instead of reform, demoralization; instead of law, I find lawyers; instead 
of justice, oppression. What Carnival King ever found a city so well prepared for him? I guess I shall leave at once; for I have no work to do as yet in Louisiana."

But before leaving, the Devil took a notion to alight upon the top of the State House to watch the Convention. He listened for several hours to the proceedings, much to his own surprise; and it was nearly three o'clock before he knew it.

"Half-past two o'clock on Friday," muttered the Devil; "and I have to be in Pandemonium by a quarter to three. I don't quite like the state of affairs in that old hotel; but I doubt if the situation really demands my presence; I think I shall send a subaltern up to the Convention; for the Devil's interests are not sufficiently represented. But I shall not come back here for twenty years. What is the use of staying in a city that is going just where I am going? Besides, if anything serious happens, my representative can inform me. They have an embargo on reform here, it seems to me - just as they have on commerce. After all, New Orleans in 1879 is not very much holier than New Orleans in 1866. I guess I'll adjourn."

And he adjourned, after having copied the word "Choppinism" into his new Dictionnaire Infernale. 


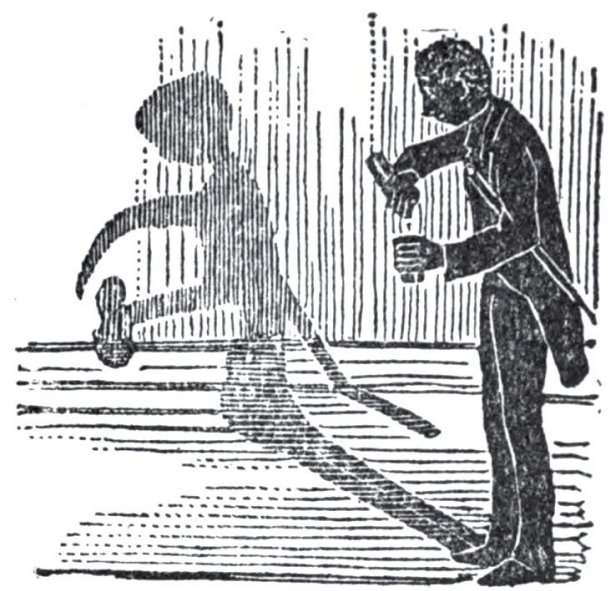

\section{QUACK! QUACK!}

Item, August 20, 1880

Quack! Quack! I am on the rack. You promised to end my pain;

For a little wealth you'd restore my health You said; yet here I've lain

For weary weeks and for mournful months, With pangs that are only known To the tortured victim of the Quack, When his faith to the winds has flown.

Death's shadow falls on my barren walls, It sleeps on my chamber floor.

Its marrowless bones mock at my groans.

And point to the shining shore, 
While a jeering, mocking, ugly grin

Spreads over its fleshless face

At a double triumph - the Quack's success, And the Quack's supreme disgrace. 


\section{Complaint of Creole BOARDING-HOUSE-KEEPER}

Item, September 27, 1879

O la canaille! la canaille! All time after dis I will make dem to pay in advance.

De first dat I have, say he vas a capitaine. I know not if he vas a capitaine; but he vas a misérable. After he have eat and sleep here six week and not pay me, I tell him, "Monsieur, I must money have."

He say: "Madame, you take me for tief?"

I say: "Monsieur, it is right dat you pay; I have wait long time assez."

He den say: "I learn you how to speak me in a manner so much insolent. Now, I not pay you till when I be ready, and I not hurry myself."

"Go out from my house!" I say.

"I go out, madame, from your dirty house when it me please" - dat how he speak me. And I could not force him to part till when I had take all de furniture out from his room. He owe me not more as seventy dollaire!

... After, I have one Frenchman, I tink him well elevated - le coco. He nail his valise on de floor for make me tink heavy; and he dispar one night - owing me forty-nine dollaire! I find noting in his valise only one syringe.

... After, I have two married. Dey pay me enough well, until when de woman run away wit some oder man. Her husban' stay till when he owe me eighty dollaire, After, he go too; and write me letter as dis: 
"Madame, I cheat you of eighty dollaire; and I not wish only I could cheat you of eighty thousand dollaire. It was for cause of you dat my wife have run away."

After, I find out she was not his wife.

... Den I have a sick man. He fall on de banquette in face of my house, and I take him in to nurse. When dat he get well he tell me he vas one professor of langedge. He eat and sleep here four mont; and first he pay a little. He complain much from noise. He vas what you call nerveux - so like I was oblige for to make my daughter walk witout shoes in naked foots; and we to speak in dumb and deaf langedge by fear of make him trouble. He smoke in de bed and burn de cover; also he break de pot and de cradle-chair, and after, de window, an' de armoire an' de - vat you call de pendule; - he let fall ink on de carpet, and he spit tobacc' on de wall, and he vomit in de bed. But I noting say, as he not 'ave baggage; - ainsi, wen he owe me forty dollaire I not want turn him out for dat I get my money more late. When at de end I tell him to go out, he tell me he have receive a checque and pay me on Monday. But I nevaire see him after. He owe me one hundred and sixty-seven dollaire - and seventy cent vat I lend him for medicine to buy.

... After, I have one woman, species of camel (espèce de chameau) and one doctor, her husband (tout ce qu'il y avait d'abominable). She pretend to be - and you call dat? - sage femme; and he is not so much doctor as my cat; but for all dey doctor me for two hundred and fifty dollaire, and I not ever obtain of it not one sou. 
... After, I have tree familee - all vat vas of rough and ugly; for one mont I not receive of rent. So I serve to dem notice of quit. But dey tell me dey not me pay nevaire, and not quit until when I make law-suit. Eh bien, de rent of de house vas not more as fifty dollaire, and de law cost me perhaps one affair of more like one hundred dollaire. Ainsi, I quit de house, an' leave dem all dere to do like dey would please. But before dat I could leave, dey steal me two buckets, and one stove, and one broom, and one clock, and one iron, and one coffee-mill, and one hen, and one leetle cat vat I much vas fond of, and one plate, and some linen of womans vat to me not belong. 


\section{THE BOARDER's REPLY}

Item, September 28,1879

Est-ce que vous vous fichez de moi? 'cré nom! No: I not no more pay my rent in advance, because dat I have not of fait in permanence of businesses in Orleans.

Wen I am first come I take myself a room in de Rue Bourgoigne. Dey have in first floor one bear, one parrot, and two macacs and several of cats of Malta; and wen dat I enter myself to pay my rent, I see all dat to move itself about inside. De woman was of color vat you call one mulatresse - and I pay in advance like one animal!

After vat I have live in de house six week, I not to her owe noting, but she me owe one affaire of ten piastres more as my rent vat I ever pay in advance; for dat she me come near every day for borrow one quarter of piastre or one half of dollaire, or two dollaire, and she smile and make so many funny bêtises dat I not could her noting refuse. After dat I be dere two mont, she owe me two mont of room in more as I have her pay in advance.

After a little of time I not see more de little beasts; - she have sell de macacs and de bear for herself obtain money. And I vas well content dat de parrots not dere vas more; - it vas true little demons vas not allow to nobody to repose himself.

One night I not come home until twelve past, and I not hear noting of noise. After I enter into my room, and I find noting inside - no bed, no chaise, no armoire - noting only my linen-dirty and my blue 
trouser-old. All de house empty; all de rooms naked personne in its inside. She not have not pay her rent - so, by consequence, dey seize demselves de furniture and have clean out de house - of such way as I find myself have to sleep on one floor much hard and all vat dere vas of dirty. And never again I not noting see of de woman of color vat owe to me near twenty of dollaire.

... But I stay in de house, for one oder woman of color enter in morning; and she have much of furnitures. I explique myself to her, and she tell me in Creole - "To s'ré resté 'vec moue, mo to donné belle chamb' garni asteur, pou' même prix."* And I myself dere install. She ask me dat I pay in advance; and I not like for refuse, like I not have time for look for more rooms. C'est égal, say to myself I.

Sometime she clean well my room; and sometime she not it clean not of all. Sometime she permit to strange mens of color dat dey enter my room; and dey permit demselves to lie upon my bed wen dat I was out in way to make a walk. I not was content; but could noting do, for dat I have pay in advance.

One day she desire to buy a miroir, and she ask me dat I pay, for dat she not have of money; and she tell me her husband me pay wen he have de Saturday next arrive. I so pay, like one kind of beast vat I be; and

* Editor's Note: The Gumbo, or Creole, given above may best be rendered into the Gullah of our English-speaking coast thus:

"You be stay wid me, me gib yo' fine fuhnish' room nownow, fuh same price." 
before dat come de Saturday, one sheriff take all vat vas in all de house; and I not vas able, never already, to obtain vat she me owe. Also I since inform myself for as she had noting of one husband.

... I be myself disgusted; and I take myself room in house of one white woman, de vat me ask dat I pay in advance. After, she not me well treat. She take from out my room one cradle-chair and much more of furniture, de vat she say vas not put inside but for ornamente. She have children vat tear my book, and one locataire steal my trouser, and one steal tobacco, and one steal my soap. Never I could myself keep a little of soap. I have dere one essuiemains for more as two week.

I pay first of mont after. Second of mont I come home, and I see a - vat you call vente à l'encan; and one woman come to have take away my book - one affair of fifty book. Never can I arrive to procure again de money to me, nor even to find where live de woman vat have take my book.

... One time of more I pay in advance. De lady was of France, and she had de face beautiful and de heart good. She not me treat but too much well. I have rest in her house forever; but I not rest long. I pay my rent ever de fifteen of mont. I pay de fifteen of Avril. De sixteen, she die quick of vat you call mort subite. Never I see in it-not-matter-what-oder-country of tings pareille. Not again do I be so much beast for in advance to pay. 


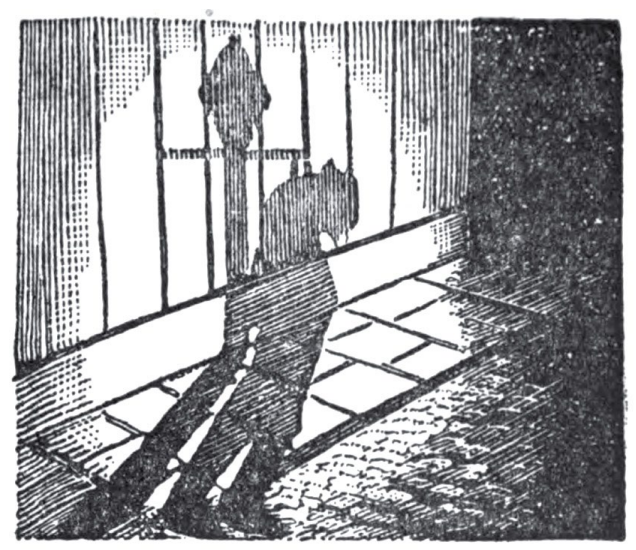

\title{
Coming Events Cast Their SHAdOWS BEFORE
}

\author{
Item, August 19, 1880
}

It will come sooner or later; but the parties who should be most interested in such matters do not pay any attention to the shadows of coming events. The Widow with Wooden Legs, as the Spaniards call the Gibbet, is waiting to celebrate her nuptials with some of our hoodlums; and yet the latter do not seem to know it. A long time has elapsed since the Widow was last married here, although the number of fellows who ought to have been married to her by force is legion. She is becoming tired of widowhood; and this is leap year. She is going to propose pretty soon; and when she proposes it will be no use to try backing out. 


\title{
Why Crabs Are Boiled Alive
}

\author{
Item, October 5, 1879
}

And for why you not have of crab? Because one must dem boil 'live? It is all vat is of most beast to tell so. How you make for dem kill so you not dem boil? You not can cut dem de head off, for dat dey have not of head. You not can break to dem de back, for dat dey not be only all back. You not can dem bleed until dey die, for dat dey not have blood. You not can stick to dem troo de brain, for dat dey be same like you - dey not have of brain. 


\title{
a Creole Journal
}

\author{
Item, October 5, 1879
}

I read to you of my journal-book - how he do:

Jan. 1 - Mon cher, lend to me one little affaire of ten dollaire, and I pay de 1st, wit good intress. Ah! you be good friend. I be possess of money; but for now I have of de expenses large.

Feb. 1 - Mon ami, I much sorry for dat I not can you pay to-day; but soon I you pay wit grand intress. One mus' not ever angry himself for ten dollaire.

March 1 - Mon bonhomme, I not can you pay, not wen as I have of money. You be too much of impatient. I much sorry for dat I ever ask of you money.

April 1 - Monsieur, I not have ever suppose dat you like more one miserable ten dollaire as my friendship. I not ever more ask of you one faveur. I not like you speak me so.

May 1 - For wat you lend me money like one Imbecile? I more like owe one tousand dollaire as ten for dat I more be respected. I be tramped upon for dat I owe one dirty ten dollaire. You be pay some one day.

June 1 - You are one Insolent! If suppose for dat I do owe to you one miserable dollaire! Is it dat you are one beggar and have of hunger, for dat am I to be ask all time? You take me as one Imbecile? Not have I tell you I pay wen I can? I not will myself suffer more to be insult for one dirty dollaire.

July 1 - To-morrow I can you pay. I hope to ask dat you do me one little faveur - to ask dat friend to you 
dat he give me one place like collecteur or secretaire. August 1 - I not pay until wen I can one place obtain.

September 1 - I not pay until wen sugar come in de market.

December 1 - I not pay ever at all. I not you noting owe. I not suffer dat I be eternal ask for money. I not speak you not more. Go to devvel for you ten dollaire, for dat I not slap you de visage. 


\title{
The Restless BoARder
}

\author{
Item, October 27,1879
}

He come to me fust of de mont, an' say, "Madame, I must another room; I not can live in dat for de noise abominable vat make dose infants." And I reply him, "Monsieur, choose yourself vat room mos' you like."

Den he tell me to get him arrange one room on t'ird floor. I get room right morning. Evening he say, "Madame, I not can take dat room; I take back oder." So I change him de tings well more.

Next week he say, "Madame, I must anoder room obtain; I not can suffer more de noise of devils vat dose infants make." So I arrange room on fourt floor. In de evening he tell me his mind be change - dat he not more want dat oder room. So I have all for to move back again.

After, he come to me de t'irte-et', and say, "Madame, you get to me one oder room, dat for I not leave de house. No more can I suffer de noise infernal and outrajeous vat make dose infants detestable.” I say, “ Monsieur, take vonce vat room you deseer, and leave me tranquille."

He den take room on front floor; but in middle night he go down gentle de stair and put all tings updownside, and go back in ole room. Den in de morning he tell my domestique to him aid, an' for more as five hour dey walk up de stair an' down de stair carr'ing much of valise an' of trunk an' of ole pantalons an' of washing-basin an' of pillow - and of pot. De vat me disguss. 
At de end all at sudden he take oder room, and dere install him well - vat I much surprise. But not more be I surprise ven dat I see him go out from de house, away, an' one negro vat carry him de valise. And much be I content for dat I see it.

But I not long content.

De morning after I see a procession vat enter de house one time more - de negro, de valise, and he, and one boy vat carry him de tobacco-pot and boots. So he go up de stair, and put back himself to his ole room. Not ever in-no-matter-vat-place see I such tings.

Den he come to me an' say, "Madame, so some one ask after me, tell dem dat I am one mad." "Certainlee," I reply, "I will so dem tell, for dat it be true." But I not understand vat he mean precise until one hour more. Den come to house one man who ask if dat he vas not live here.

"Ah, oui," I say, "he live here, but he is one mad."

"So it is," he reply, "I tink; for as he come to pay me one mont advance, and never not again come back. So you give to him back his monis."

Den I be sorry for dat I tell he vas one mad; for dat I see he not one mad at all; - but only one devil vat desire torment all person vitout paying for his vickedness. So I give to him de money, but notice of quit he not take; and I not can yet guess how far dat I be get rid him. 


\title{
FURNISHED ROOMS
}

\author{
Item, November 2, 1879
}

I not understan' for vat some peoples ask of prizes so much elevate for dere garneesh room - I much mistruss myself of such, peoples; - I believe dey all be of vat mos' vicked.

Firs', I go for ask prize of room in my street of de --, for dat I observe of sign "Room garneesh" at door. Dey to me show one room well garneesh on t'ird floor - one big more as one cell of monk, an' I ask of dem de prize. Dey tell me de prize be t'irty dollaire by week. So dat I find myself much astonish, and I ask for see one oder of room. So dey show to me one oder of room on second floor; an' I ask de prize - ven dey tell to me forty-tree dollaire by week. It be one room of behind; so I demand for dat I see one room of before for curiosité. Den dey tell me vat de room of before be fifty dollaire for me, but for any oder one seexty dollaire by week. So I begin to take dem for mads; and dey ask me if I not deseer to see one room of de firs' floor, an' I say, "No - deveel! Vat for I see one sacré room vat cos' one hoondred dollaire? - better as I buy to myself one hoondred dollaire of mustard!" "Not one hoondred of dollaire," dey tell - "not more as one seventy-five dollaire."

And ven dat I save myself from de house away, dey laugh like all vat be of mos' idiot. Seventy-five of dollaire! Seventy-five tousand of deveels!

After I go see again more of house, and I find myself all astound. For de room vat I see of mos' good 
market dey ask seexteen dollaire by week - it be vat you call one attique. Oder rooms not be more as seventee, eightee, one hoondred dollaire by mont - always in advance to pay. Vat mos' I have not understan' be dat I not see one room rent in all of house - not even one. It make me to tink vat dey not ever be rent - even for dat dey have sign “ Room garneesh.” And I tink dey all vat be of mos' vicked - for dat how can dey make for pay rent vit room empties vitout as dey be not honeste? It is so as I tink, and I tink also dat de poleeses not ought - but de poleeses! de poleeses! to vat good dat I talk of de poleeses! 


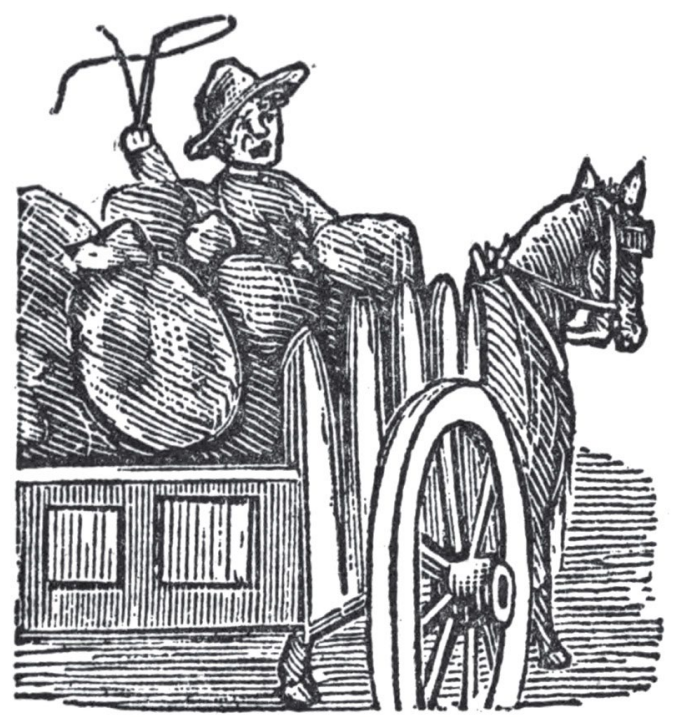

\section{Char-Coal}

Item, August 2, 1880

Black: - coalee - coaly!

Coaly-coaly; coaly-coaly; coal-coal-coal.

Coaly-coaly!

Coal-ee! Nice!

Cha'coal!

Twenty-five! Whew!

O charco-oh-oh-oh-oh-oh-lee!

Oh-lee!

Oh-lee-e!

[You get some coal in your mout', young fellow, if you don't keep it shut.] 
Pretty coalee-oh-ee!

Char-coal!

Cha-ah-ah-ahr-coal!

Coaly-coaly!

Charbon! du charbon, Madame! Bon charbon?

Point! Ai-ai! Tonnerre de Dieu!

Char-r-r-r-r-r-r-rbon!

A-a-a-a-a-w! High-ya-a-ah! High-yah!

Vingt-cinq! Nice coalee! Coalee!

Coaly-coal-coal!

Pretty coaly!

Charbon de Paris!

De Paris, Madame; de Paris! 


\title{
Mexican Coins
}

\author{
Item, November 3, 1879
}

"Sit down, O sunburnt wanderer, sit down! - Well, well! And whence comest thou?"

"I come," he observed with grim solemnity, "from Mexico."

And he laid upon the table a striped blanket, a worn valise, and a heavy leathern bag whose contents clattered like castanets as it struck the mahogany - Mexican gold.

"Why, we thought you were dead - all these years, and not a word!"

"Dead!" he echoed; "yes, I was dead, dead to the century for which I was born, and to modern civilization - dead from 1870 to 1879 . I feel like one of the Seven Sleepers awaking to find himself moving in a new age; I have been living in the seventeenth century, and suddenly I find myself in the nineteenth."

"In Mexico City?" we suggested.

"No: in Mexico City one hears at least some echoes from the outer world - no, in Matamoras and Sonora. Mexico City belongs in some respects to the present century; the life of the provinces does not. Time seems to have stood still there for two or three hundred years. The printing is certainly of the sixteenth century; many manufactures are even mediæval; and agriculture is antediluvian. I knew an American who was idiotic enough to attempt the introduction of steel ploughs - he would not have dared to speak of modern machinery." 
"And he -"

"Became instantly an object of suspicion and detestation. Had they not their good wooden ploughs, such as were used in the time of Montezuma, and before him? - And why should a cursed Gringo come to them with ploughs of steel?"

"And the money?"

He took a yellow coin from the wallet and held it up. On one side the Mexican eagle strangled its serpent victim; upon the other a naked arm upheld the Cap of Liberty before the open pages of a book, whereon appeared the syllable "Ley."

"They say the coins of a country indicate to some extent its social condition," he said. "See how rude and coarse the milling is compared with that of the American coin. There is a suggestion of the barbaric in it. But I like the eagle better. There is a ferocious grace in its poise which makes the idealized American bird seem stiff and clumsy by comparison - I admire that savage eagle, tearing the serpent to shreds; - but it is a symbolic lie; there is nothing of the eagle in the Mexican and much of the serpent. The whole design is a lie. There is the Cap of Liberty; and yet there is no true liberty of thought and speech in Mexico; - there is the word 'law'; and they have no law; they are sans foi ni loi ni roi. The coin is a braggart like the Mexican. Truly free nations do not boast too much of law and liberty."

"And the Exposition?"

"Ah, bah! - the Exposition! What have they to exhibit? Knives and revolvers and wooden ploughs?"

"Nothing else?" 
"Ah, yes! - one Thing! — the one Thing in which Mexico defies competition. I believe I have brought a few specimens in my serape - magnificent specimens - which defy rivalry."

But when he ceased to speak, no answer fell upon his ear, and, turning himself thrice about, he found himself alone. 


\title{
Louisiana People Not Gay
}

\author{
Item, November 4, 1879
}

"It seems to me," said the Parisian, "that in spite of an exquisite climate, the people of Louisiana are one of the most solemn-faced I ever saw. There is no real gayety under this glorious sky. People seldom laugh here; when they do, the laugh is apt to be cynical. Workmen do not sing while they work; boys seldom whistle when they go along the street. The farther south I go, the more I find this to be the case. It is true, the negroes sing; but their melodies are the saddest and weirdest I ever heard. Why, in Paris the workshops are merry as birds' nests - it is one ceaseless caroling from morning till night; and in European countries the singing of laborers and farmers is proverbial; song appears to be a part of their existence. I fancy that there must be something sad in the very intensity of life near the tropics."

"In some respects I agree with you," said the Englishman; "but I think the difference is due to the nature of the country. People do not sing in low flat countries, nor do they give vent to much reckless merriment. They sing in the mountains, and laugh among the hills. The hilly countries are the musical countries. Man seems happier the nearer he lives to the stars. It is not in low plains watered by great rivers like the Nile, the Ganges, or the Mississippi, that we need look for merriment; but among the mountain districts of Europe and America.” 


\title{
A Creole Courtyard
}

\author{
Item, November 11, 1879
}

An atmosphere of tranquillity and quiet happiness seemed to envelop the old house, which had formerly belonged to a rich planter. Like many of the Creole houses, the facade presented a commonplace and unattractive aspect. The great green doors of the arched entrance were closed; and the green shutters of the balconied windows were half shut, like sleepy eyes lazily gazing upon the busy street below or the cottony patches of light clouds which floated slowly, slowly across the deep blue of the sky above. But beyond the gates lay a little Paradise. The great court, deep and broad, was framed in tropical green; vines embraced the white pillars of the piazza, and creeping plants climbed up the tinted walls to peer into the upper windows with their flower-eyes of flaming scarlet. Banana-trees nodded sleepily their plumes of emerald green at the farther end of the garden; vines smothered the windows of the dining-room, and formed a bower of cool green about the hospitable door; an aged fig-tree, whose gnarled arms trembled under the weight of honeyed fruit, shadowed the square of bright lawn which formed a natural carpet in the midst; and at intervals were stationed along the walks in large porcelain vases - like barbaric sentinels in sentryboxes - gorgeous broad-leaved things, with leaves fantastic and barbed and flowers brilliant as hummingbirds. A fountain murmured faintly near the entrance of the western piazza; and there came from the 
shadows of the fig-tree the sweet and plaintive cooing of amorous doves. Without, cotton-floats might rumble, and street-cars vulgarly jingle their bells; but these were mere echoes of the harsh outer world which disturbed not the delicious quiet within - where sat, in old-fashioned chairs, good old-fashioned people who spoke the tongue of other times, and observed many quaint and knightly courtesies forgotten in this material era. Without, roared the Iron Age, the angry waves of American traffic; within, one heard only the murmur of the languid fountain, the sound of deeply musical voices conversing in the languages of Paris and Madrid, the playful chatter of dark-haired children lisping in sweet and many-voweled Creole, and through it all, the soft, caressing coo of doves. Without, it was the year 1879; within, it was the epoch of the Spanish Domination. A guitar lay upon the rustic bench near the fountain, where it had evidently been forgotten, and a silk fan beside it; a European periodical, with graceful etchings, hung upon the back of a rocking-chair at the door, through which one caught glimpses of a snowy table bearing bottles of good Bordeaux, and inhaled the odor of rich West India tobacco. And yet some people wonder that some other people never care to cross Canal Street. 


\title{
The Creole Character
}

\author{
Item, November 13, 1879
}

It was not a difficult job to put up a wooden awning about the corner grocery - two stout Irishmen would have done it in twenty-four hours; but the corner grocery man was a Creole, and he hired four Creole carpenters. So they took three weeks to do it, and they have not done it yet. Ce pas baptême katin, travail comme ça; and they did not propose to work themselves to death. Life was too short. We went round the corner to look at them. Beautifully did they saw the boards and with exquisite grace did they hammer the nails - vrais poseurs they were; and then they wiped their brows and sighed, and rolled up cigarettes and went into the grocery to get a light. There they met Aristide and Jules and Albert and Alcée and Alcibiade, and they all took a drink and cracked awful jokes together. Then the carpenters went out again, and climbed upon the half-finished awning, and grinned at a swarthy young woman passing, who had a graceful air of deportment and a complexion like a statue of bronze. Then they laughed at one another; and it began to rain, so they went down and smoked some cigarettes, until it was time for dinner. After dinner they worked very slowly, deliberately, and artistically for ten minutes, until a mad dog came running down the street, which they chased for half a mile with surprising energy and astounding strength of purpose. And when they came back they recounted their heroic deeds to an admiring crowd in the grocery, and to the 
washerwoman round the corner, and the Italian fruitwoman over the way, and the wife of the rival grocerykeeper on the other side, and the two lazy policemen on the beat, and the cook of the neighboring boardinghouse, and the confectioner at the southeast corner, and the shoemaker at the northwest corner, and the butcher at the southwest corner, and the coal woman just round the northeast corner. Then they got ready to work; and commenced to hammer away to the air -

"Madame Caba,

Tiyon vous tombe;

Madame Caba,

Tiyon vous tombe;

Ah, la reine,

Piye la su' moi;

Madame Caba

Piye la su' moi;

Madame Caba

Chandelle 'te teigne," etc.

Then it got dark, and they took another drink and went home. And it was even so next day also, and the next, and so for twenty-three days; and that awning still remains in a wild and savage condition of incompleteness. 


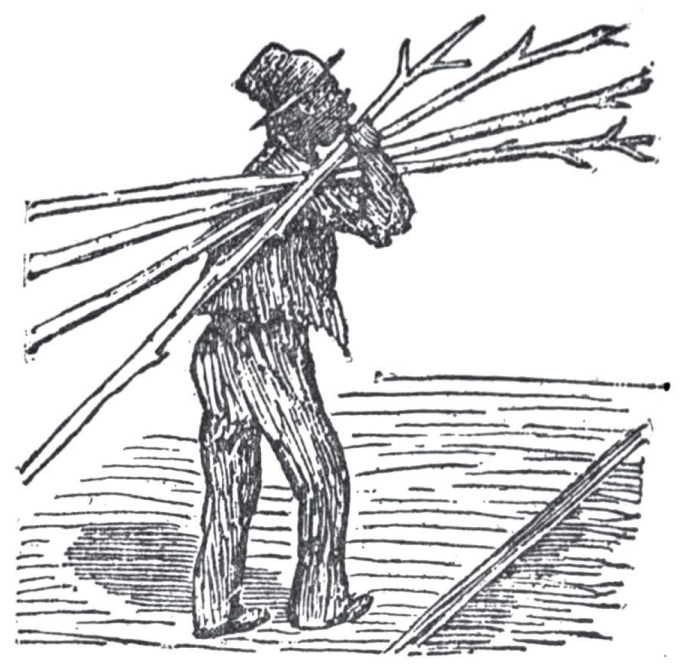

\section{Des Perches}

Item, August 30, 1880

Daily he goeth out beyond the limits of the city into lonesome and swampy places where copperheads and rattlesnakes abound.

And there he cutteth him clothes-poles, wherewith he marcheth through the city in the burning glare of the sun; singing a refrain simple in words but weird in music.

A long and lamentable sobbing cry, as of one in exceeding great pain and anguish.

So sorrowful in sooth that the sorrow of the city drowneth the sound and sense of the words, - the words chanted in ancient Creole patois - 
And we, listening to the cry, gave ourselves up to solemn meditation;

Dreaming of the cries of anguish that arise when a clothes-line, heavily burdened with its snowy freight, falleth upon the mud;

And the poor little woman sitteth down and crieth till her eyes are red, ere she findeth courage to commence all over again, and mend the clothes-line.

It is to avoid these things that men should buy clothes-poles.

Des perches!

And hearing the ancient negro once more lifting up his voice, we also remembered

That often in the dead waste and middle of the night, while meandering about the black backyard,

We were suddenly and violently smitten on the nostrils by the treacherous clothes-pole, hidden between lines of white sheets and shirts that waved their empty arms like spectres.

Also, we remembered how the wet linen fell upon our sacred person; and how we tried to lift up the clothes-pole again but could not; -

For the cunning of the washerwoman was not given to us.

But notwithstanding these things we do bless the clothes-poles, and him that sells them, remembering the service they do to the indispensable washerwoman.

Des perches! - des perches! 


\section{A Kentucky Colonel RENTING Rooms}

Item, November 15, 1879

"AH, one ting more - de name of monsieur?"

"Colonel Zachariah Mart -"

"Alors, alors, it must dat monsieur pay to me of advance."

"But why in thunderation didn't you tell me at first?"

"Ah, because monsieur did not tell to me vat he be one Colonel. I not have, monsieur, of fait' in peoples military. Dere vas one Captain vat swindle me of sixty dollaire, one Major vat cheat me of fifty dollaire, one Doctor Military of t'irty-nine dollaire, one Colonel of one hoondred and elefen dollaire. And dere vas one General vat ask me de oder day-"

"Yes, ma'am; but that don't apply to the Kaintucky -"

"Attendez donc, monsieur, until I be finish! De General say he nevaire pay of advance, but only all de tree mont. And den I tell him I not can do. He go way; so after I hear vat he owe tree hundred and ninety-seven dol-"

"But d-! excuse me, ma'am! I'll shell out for a month in advance!"

"One mont! Den, monsieur, I not ever can believe dat you ever have be one Colonel!"

"Well! I’ll be Jehovahly - ... !!!"

"Pauline! en haut-là! Descendez donc pour m'arranger cette affaire. Je suis tout embaralificotée!!!” 


\title{
The Dawn of the Carnival
}

\author{
Item, February 2, 1880
}

The Night cometh in which we take no note of time, and forget that we are living in a practical age which mostly relegates romance to printed pages and merriment to the stage. Yet what is more romantic than the Night of the Masked Ball - the too brief hours of light, music, and fantastic merriment which seem to belong to no century and yet to all? Somehow or other, in spite of all the noisy frolic of such nights, the spectacle of a Mardi Gras Ball impresses one at moments as a ghastly and unreal scene. The apparitions of figures which belong to other ages; the Venetian mysteries of the domino; the witchery of beauty half-veiled; the tantalizing salutes from enigmatic figures you cannot recognize; the pretty mockeries whispered into your ear by some ruddy lips whose syllabling seems so strangely familiar and yet defies recognition; the King himself seated above the shifting rout impenetrable as a Sphinx; and the kaleidoscopic changing and flashing of colors as the merry crowd whirls and sways under the musical breath of the orchestra - seem hardly real, hardly possible to belong in any manner to the prosaic life of the century. Even the few unimpassional spectators who remain maskless and motionless form so strange a contrast that they seem like watchers in a haunted palace silently gazing upon a shadowy festival which occurs only once a year in the great hall exactly between the hours of twelve and three. While the most beautiful class of costumes 
seem ghostly only in that they really do belong to past ages, the more grotesque and outlandish sort seem strangely suggestive of a goblin festival. And above all the charms of the domino! Does it not seem magical that a woman can, by a little bright velvet and shimmering silk, thus make herself a fairy? And the glorious Night is approaching - this quaint old-time night, star- jeweled, fantastically robed; and the blue river is bearing us fleets of white boats thronged with strangers who doubtless are dreaming of lights and music, the tepid, perfumed air of Rex's Palace, and the motley rout of merry ghosts, droll goblins, and sweet fairies, who will dance the dance of the Carnival until blue day puts out at once the trembling tapers of the stars and the lights of the great ball. 


\title{
A Mexican's Gratitude
}

\author{
Item, April 12, 1880
}

A pretty little story comes to me from Algiers.*

Some years ago, during the spring months, a vessel sailing from Vera Cruz arrived at this port with a swarthy Mexican crew. While toiling under the hot sun, one of the men became seriously ill; and when the vessel was ready to sail, it was found necessary to leave him behind. The circumstances are not precisely known to us, beyond the fact that a young girl found him early in the morning lying in the shadow of a pile of timber, a prey to one of those strange fevers that make one shiver with cold even under a sky of fire. He asked for water in his broken English, and the girl procured assistance from her home, which was not far off. Pity prevailed over all other considerations, and the stranger soon found himself in a comfortable bed with good medical attendance. The girl and her mother watched by his bedside and nursed him until he got well again. As he was only a poor sailor, utterly penniless, he could not even offer to recompense them: and as he could not speak English beyond such few words as a stranger picks up in a foreign port, he could not even thank them by word of mouth. Before he had even fully recovered his health, he left the house in spite of the old lady's remonstrances, and, kissing her hand with every sign

* A suburb of New Orleans. 
of gratitude, he went his way. As he was never seen there again, it was supposed that he had been able to ship upon some Spanish vessel.

... Long afterward, it happened, by some strange chance, that the young Algerine above referred to found herself in the City of Montezuma. She had been married and was accompanied by her husband. One morning, just as the two had turned from the Plaza into a side- street a small, swarthy man, with gold rings in his ears, and carrying a large basket on his back, approached them, fixed his black eyes for a moment on the young lady's face, and with the sole explanation, "Madre de Dios! es la senorita!" fell upon his knees in the dirty street, and, seizing her hands, covered them with kisses, while tears of gratitude streamed down his bronzed face. The husband, a Cuban, who had often heard the story of the sailor, naturally understood and accepted the situation; while the little Mexican poured out his soul in comparisons of the young wife to guardian angels and saints and virgins, and in those strangely beautiful Spanish compliments which, when sincerely uttered, caress the soul of the hearer. And then, unfastening the strap of his basket and exposing its tempting cargo of luscious fruits and rich flowers, he besought her, upon his knees, to permit him to bear it to her residence as a gift.

"Tell him," she said to her husband, who acted as interpreter, "that we cannot accept his present, and that the pleasure of having been able to help him when in need is more than sufficient compensation for the service." 
He begged so hard, however, that she was obliged to accept a handsome bouquet of flowers, and, imploring all the saints of Heaven to bless her, he departed sadly with his basket.

But it seems that he followed her home unawares; for every morning afterward, during her stay in Mexico, just as the mountain-peaks commenced to flush in the rosiness of dawn, the servant was awakened by a knocking at the street-door, and opened it only to find there a basket of fair fruits and tropical flowers that exhaled a perfume as passionate as the gratitude of the giver. 


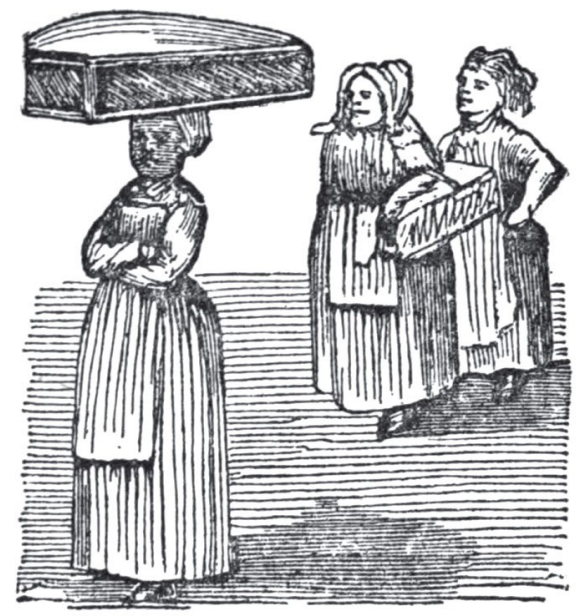

\section{WASHERWOMEN}

Item, August 31, 1880

The washerwoman is a creature of which there are various species.

There is the washerwoman who works very cheap; but who never gives you back your own socks or undershirts; and the exchange is invariably to your disadvantage.

There is the washerwoman who makes it a rule of life to wash off all the buttons of your shirts and pull all the strings off your drawers and never dreams of putting them on again. This washerwoman charges like sixty.

There is the washerwoman who puts the thinnest kind of starch in your shirts, so that they become limp 
rags after being worn an hour. This kind of washerwoman gets rich fast. She has an eye to business.

Then there is the washerwoman who promises to bring your clothes at a certain hour, and never does so under any possible circumstance.

But there is also the good, honest, industrious, prompt, and motherly or sisterly washerwoman who puts buttons on your shirts and darns up your socks and does not charge extra therefor.

We looked for such a washerwoman for two years before we found her. Now we wouldn't give her up for a small fortune.

If washerwomen have their faults, it must be remembered they have their trials and afflictions. Many of them have been spoiled by bad treatment.

There is no sort of thieving so contemptible as to beat one's washerwoman; but we doubt if any other class of working-people are so much victimized.

It is pretty rough to labor hard all the week, working until one is ready to drop down with fatigue; obliged to watch changes of weather; obliged sometimes when a clothes-line breaks to do all the work over again; obliged to furnish one's own soap and starch and blueing; -

And then to carry the work to those who ordered it, - all nice and clean and pretty, - expecting to receive the just reward of one's labor; -

But, on the contrary, to receive nothing but lying promises and sometimes even hard words; -

And then to go home hungry; and to sit down and cry because there is not a cent in the house! 
No wonder the poor women often say it is better to be a sieve than a washerwoman.

No wonder that washerwomen should sometimes feel disgusted with their work, and cease all effort to try and please, and tear off buttons and pull off drawer strings with rage and fury.

It isn't their fault if they are not always angels. 


\title{
Attention! Azim!
}

\author{
Item, July 8,1880
}

EDITOR CITY ITEM - Your columns contained a few days ago a recipe for gombo which contained neither okra filé nor fine herbs. Please give one from a genuine Creole cook, omitting nothing of the delicious compound so dear to Crescent City gourmands, and made in perfection nowhere else.

AzIM

We have just been to see a "genuine Creole cook," and one of the best in the city, who gives us the following receipts:

\section{GOMBO FÉVI}

A whole chicken - if chicken cannot be had, veal will serve instead; a little ham; crabs, or shrimps, or both, according to the taste of the consumer; okra according to the quantity of soup needed; onions, garlic, parsley, red pepper, etc. Thicken with plenty of rice. The gombo févi is made with green and fresh gombo or okra cut up. It would be no use to attempt to lay down rules in regard to the proportion in which the above ingredients are to be used, as there are not, perhaps, two Creole cooks who follow the same recipe exactly. Everything depends on taste and experience.

\section{GOMBO FILÉ}

This is made exactly like the other, but with pulverized okra instead of fresh green okra, and oysters are also 
used, in proportion to the quantity of soup needed. If Azim needs further information, he must inform us, and we shall send him to a first-class Creole cook, with whom he can converse at leisure.

We fear that the good old Creole lore is rapidly disappearing, not merely in regard to cooking, but also in regard to natural medicine. The herb medicines of the old Creole nurses were matchless; and doctors were seldom called into Creole homes in the old days except in desperate cases. There were family secrets in regard to tisanes and cataplasms and purgatifs which boasted a San Domingo or a Martinique origin, and which many good old black women averred had come from Africa in the first years of American slavery the only heirlooms which aged obi-men could bequeath to their slave children. Many of these secrets are kept with something of religious awe. Neither love nor money nor menaces could extort them from the owners. If childless, it is more than likely the secret will die with their owners; if they have children, these generally inherit the mystical power, but hardly ever do they seem in this generation to obtain the success of their fathers and mothers. We have often suggested that all the extant knowledge in regard to Creole cookery and herb medicine, so far as it is possible to obtain it, should be collected and published. Such a publication would not only be a literary curiosity, but also a work of rare practical value, and we sincerely believe the editor of such a work might find the investment a paying one. It would be hopeless to attempt a complete work of such a description, for reasons which 
we have often given; but here remains a great deal which can be obtained and which is of great value. With time and leisure we should wish for no better or more agreeable employment than the collection and arrangement of such curiosities. 


\title{
An Ultra-Canal Talk
}

\author{
Item, July 13,1880
}

(Stranger approaches an ancient Creole house, rings the bell, and beholds the landlady. Landlady says something. Stranger loquitur in surprise:)

"He is dead?"

"Oh, oui, monsieur; 'e ees det, and dere is not person sorry. 'E vas all vat vas of most troublesome. All ze time vat'e liv, I have troubles vit peoples vat come to see 'im. For everybody know 'im to be one mad, who like to spend his money in foolishness and bêtises. After his son die he not have nobody for 'im look after. So dey come to sell to 'im litograph, vich dey make 'im to believe to be oil painting by great master; an' 'e pay one, two, tree hoondred dollaire for litograph vich cost no more as fifty cent. Ven I tell 'im not buy, 'e tell me I was one ignorant and one imbecile vich have not appreciation of art. After, ven'e fin' out not oil painting, 'e call zem curssed camel - two-hump camel, an' heap of robber (tas de voleurs) and charogne; an' 'e wish dem all blast by ze feefty tousand flames of hell. So zat 'e not talk of oder tings - only of robbers and liars and assassinses.

"Ven zey could not more sell to "im play-bills as oil-painting of great master, zey sell to 'im of daub as great water color picser. 'E pay seventee dollaire for vat cos' not more as tree cent each. Ze frames wort perhaps six dollaire! At las' 'e fine out how zey 'im swindle; an' 'e talk of robber an' murderer an' camel of two hump. And 'e say dis country ze most curssed 
country vat exist - all vat be of mos' canaille and racaille and charogne.

"Ven as dey not could no more to 'im sell picser, zey sell to 'im vat you call céramique, old cup and saucer and dish vat wort not more as ten cent and vat dey tell 'im from China come. 'E pay t'irty dollaire, as dey tell 'im very 'ard for find. But 'e find one day undare bottom of cup one word like 'BIRMINGHAM'; and 'e swear so dreadful vat I have me de finger in de ear to put. After 'e not talk more but of tief and liar, and of assassin and of infames and infant of ze devill and children of 'ell - vich 'e wish open and swallow zis sacré charogne de pays. And 'e also say more vat I not you dare racount.

"Also dey sell to 'im boots vat sole vat of paper was made and coat vat was glueded together, an' I not ever could 'im prevent to pay fiftee dollaire for ze coat an' ten dollaire for ze boot. Sixtee dollaire! And ven zat ze boot go into pieces an' ze coat tomble into rag, 'e could not enough to swear in such manner zat people hear 'im more as tree block. Ze same night'e swear all night so as no one could fall 'imself to sleep. 'E said tings so terrible zat I stuff to me de ears wit cotton; but all same I hear 'im swear until ze sun get 'imself up.

"After, dey sell 'im furnisser, armoire, table, bed, chair for mahogany - vat was pine covered wit sometings. 'E pay tree hoondred dollaire! Ze table was only glueded and one day it burst ven he dere put to 'im de elbow; and ze bed also only glueded together. 'E go to law, but ze oder peoples much vas rich, and 'e lose five hoondred dollaire wit lawyer an' 'e soon tire of law. 
"After zey sell to 'im vine vat not vas vine and fisky vat not vas fisky an' 'e pay like one millionaire zough 'e not have much of money. Not ever could I prevent 'im to buy or to be swindle."

"Did he say anything before he died?"

"I tink so! 'E not sick - never sick at all. 'E die sitting in ze berceuse. For'e vas very old, very, very much old. And some one came to sell to 'im sometings. 'E try to get up; but not could, and 'e not let me to help 'im. So I not help 'im; and 'e say, 'Mon bon Dieu, have me mercy - Oh, le tas de canaille! Pray you for me! Oh, les sacrés voleurs! Lord have me pity! - Charogne de pays! - I believe me in de heaven for ze good! Oh, de curssed wretch! - Holy angel 'elp me up! - Oh, ze camel of two hump! - Oh, mon Dieu, miséricorde! zis be one infame country of assassin and robbaire!' So 'e pray an' so 'e swear. So 'e die wit - 'Charogne de pays!' And ven ve sell of 'im ze picsers for vat 'e pay one fortune, dey bring not more as tree dollaire an' t'irdeen cent. But 'e 'ave near one hoondred years ven dat 'e be dead. I tink 'e ought have to be det." 


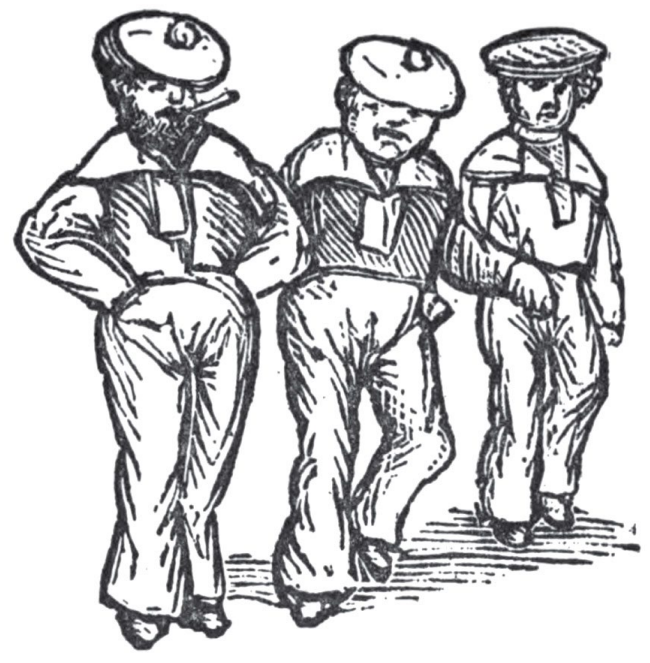

\section{Sons OF THE SEA}

Item, September 1, 1880

They come to us from the uttermost parts of the earth, with the winds that swell the white sails of their vessels. There is a sparkle in their eyes like the sparkle of a distant sea; and a faraway look acquired by the habit of gazing over the infinite expanse of rolling water. They walk with a swaying motion learned from the gait of their own ships, and there is a tone in their voices like the tone of sea-winds roaring through the rigging.

They have passed over all seas, and heard a hundred tongues spoken.

And coming into a city; leaving the rocking deck for the motionless earth, they still wear a quiet dreamy 
look, as of men accustomed to the sight of Nature in her most infinite aspect, and not liable therefore to be impressed greatly by the sight of the handiwork of Man.

But at times human frailty asserts itself; - the stern discipline of the sea has made the sailors long for some wild frolic on land; - strong drink and women hold out siren-temptations.

What wonder is it? Was not even Ulysses, that wisest of sailors, once obliged to bind himself to the mast lest the song of an enchantress might lure him to destruction?

The old sea-dogs are usually wise, like Ulysses; but the young ones will have their day.

Then again we have swarthy sailors from sunny West Indian ports, who wander about seeking for those who speak their own tongue, in order to sell odorous packages of cigars concealed in their pockets - cigars in which all the soporific fragrance of the tropics seems concentrated.

And having performed their little work of contrabandistas, they depart to enjoy a little fun with the profits thereof.

So do they sail from port to port; - more wearied by their stay on shore than by mighty wrestling with the Giant of Storms; for the whisky is not good, and there are other things which are worse.

But the sea who loves her children braces their strength up once more with the elixir of her bright winds; and drives away the fumes of a night of orgy, as evil dreams are scattered by daylight.

And as the sailors call east and west and north and 
south; buffeted by wild winds; struggling with raging waves; making brief visits to strange ports; collecting dreamy memories of foreign lands; - until the time, comes for them to sail into that weird sea which is waveless and shoreless and shadowless and forever silent, and from which no mariner ever returns. 


\title{
A Creole Song
}

\author{
Item, July 26, 1880
}

The following has been brought to us by a charming lady, herself a Creole, who tells us that it was a popular song in Louisiana at the beginning of this century:

Moin pas conné qui quichose

Qui appé tourmente moin là;

Moin pas conné qui la cause,

Cour a moin brulé comme çà.

Ah Die! Qui tourment, qui peine,

Dipis longtemps quimbé moi;

C'est tourment la passé chaine,

Plutôt moin mouri yonné fois.

Toi conné qui belle rigole

Qui coulé dans bananiers.

Où toi té sé fé la folle

La foi qui toi té baigné.

D’leau la pas coulé encore -

Des fois il 'rète tout court -

Li semble regrette encore

Li pas baigné toi toujours.

Here is a free translation:

I do not know what it is which torments me thus.

I cannot tell what it is that makes my heart beat so.

O God! what torture! what pains I have suffered so

long! 
It is worse than the pain of fetters; I had rather die at once.

Do you remember the pretty little brook that ran through the banana-trees -

Where you used to have such fun, when you used to bathe?

That water has ceased to run; -

Since the time it stopped all at once -

It seems to me it died of regret

That its wavelets could not embrace you forever.

This translation, as we have already observed, is very free, but contains the spirit of the little song. We shall be very grateful to any of our readers who will bring us some more of these curiosities. 


\title{
The Grandissimes
}

\author{
Item, September 27, 1880
}

At last it has come out in book form, this strange, weird, powerful, and pathetic story, which is certainly the most remarkable work of fiction ever created in the South.

It is difficult to render any idea of what this book is without making copious extracts. It is a dream which is not all a dream, a tale which is but half a tale, a series of pictures which, although in a certain sense created by the pencil of an Impressionist, wear a terrible resemblance to terrible realities. There are chapters which affect the imagination like those evil dreams in which dead faces reappear with traits more accentuated than the living originals ever possessed.

Is this strange New Orleans which grows up under Mr. Cable's wand our own New Orleans? It is; and yet it is something more. It is such a city as a wanderer sees by night in his dreams, who has left the shores of the Father of Waters for the icy winds and snow-shrouded scenes of some far-Northern winter; - a Southern metropolis, her streets paved with the gold of summer suns, her shadowy trees whose leaves never fall, her flowers that never die, her streets quaintly constructed like the Latin cities of the older continent, and all the motley clamor of a semi-tropical land in which even the sharp accents of European tongues lose their firmness, and old languages obtain a new softness and sweetness and languor. And there 
is all this inexpressible glamour, and yet more, in ,the familiar and yet unfamiliar New Orleans of "The Grandissimes."

If it be so with the scenes, with the characters it is also so. We have seen these characters, and yet we have not seen them. Or, to describe our own impression still more correctly, we believe that we have seen them somewhere, and yet are not quite sure - like one greeted by some stranger whose features are not unfamiliar but whose name is forgotten.

There is, therefore, a certain vagueness about the work. But it is an artistic vagueness, like the golden haze of an Indian summer softening outlines and beautifying all it touches. The old streets seemed clouded with a summer mist; the voices of the people speaking in many tongues came to the reader as from a great distance. Yet why not? Is he not looking back and listening to the speaking shadows of another era, when Claiborne first came to Louisiana?

Yet the vagueness is never too vague. Sometimes the scenes are dimmed, but it is when the reader's eyes are dimmed by that moisture which it is the artist's triumph to evoke. Sometimes the scenes become terribly vivid, however, as in the death of Bras-Coupé, or the tragic end of Clémence. There is no dreaminess in those powerful pictures. Nor is there any in that painful incident when the apothecary reads the letter to Palmyre. This scene, not even excepting the execution of Clémence, seems to us the most vividly truthful in the book. It is less tragic, less exciting, less terrible than others; but it is a genre study of inimitable verisimilitude. 
If there be one special characteristic of Mr. Cable's style that is specially striking, we believe it is his power of concentrated description. What could be more pithily forcible, more briefly comprehensive, more intensely impressive than the following description of an interior furnished in the old-fashioned Creole style? One must have seen such, however, to appreciate the power of these few lines:

... the rooms were so sumptuously furnished: immovable largeness and heaviness, lofty sobriety, abundance of finely wrought brass mounting, motionless richness of upholstery; much silent twinkle of pendulous crystal, a soft semi-obscurity - such were the characteristics.

Or this:

... The plantation became an invalid camp. The words of the Voudoo found fulfillment on every side. The plough went not out; the herds wandered through broken hedges from field to field and came up with staring bones and shrunken sides; a frenzied mob of weeds and thorns wrestled and throttled each other in a desire for standing-room - rag-weed, smart-weed, sneeze-weed, bind-weed, iron-weed until the burning skies of midsummer checked their growth and crowned their unshorn tops with rank and dingy flowers.

We doubt whether this book, in spite of its delicate merit, will become a favorite with residents of the Creole city; - its spirit has already been severely criticized by a contemporary; - its paintings are not 
always flattering to native eyes; - its evocation of dead memories will not be found pleasing. We cannot perceive that the merit of the romance is at all marred, nevertheless, by Mr. Cable's own peculiar views; and if we were inclined to criticize anything unfavorably in it, we should only question the reality of Honoré Grandissime. Was there ever a Creole of Creoles, living in such an age, who could have entertained such ideas on social questions?

There are very curious chapters upon Voudooism in this book; and we cannot share the opinion of many that it is a mere "absurd superstition." We believe it to be, or at least to have been, a serious and horrible reality; and we know of most intelligent families among our French-speaking population who share this opinion. Those who have really given serious attention to the subject have doubtless found that the traditions of Voudooism in Louisiana and elsewhere have at least as much claim to belief as the history of the aqua Tofana or of the secret poisoners of the Middle Ages.

We must specially call the attention of our readers to the Creole songs and refrains, published with the music, throughout the work. They are very curious, and possess a special philologic value. One, in particular, an African chant, sung by the negroes in cutting down the cane, deserves special notice.

But we cannot attempt to criticize Mr. Cable's book further. It must be read to be appreciated. We have not even attempted to tell the public what it is. We have only undertaken to express in a few words the peculiar impression which, as a work of art, it produces upon the reader. 


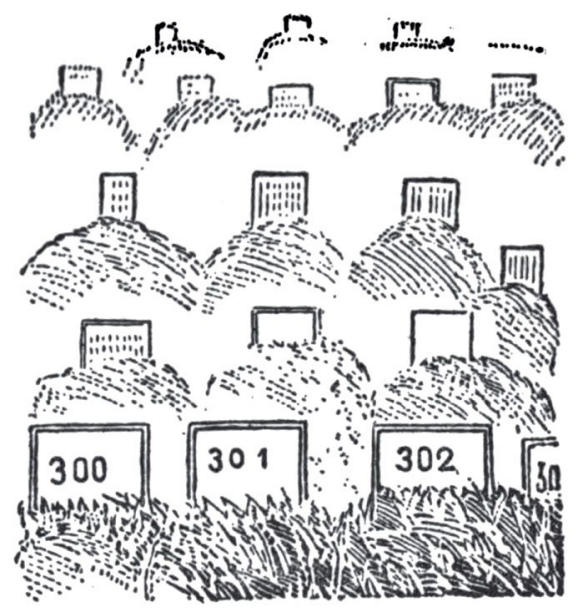

\section{The Indignant Dead}

Item, September 8, 1880

If they are not indignant as a certain worthy Administrator declared they were, they ought to be.

During the last ten years three hundred and three persons have been murdered in New Orleans or vicinity.

And yet only FIVE of the murderers have been hung.

Only five-although eleven were actually sentenced to death.

Consequently the chance of being hung for committing a murder in this community is as five to three hundred and three.

Almost as little danger of being hung for having committed murder as of being run over by a railroad 
train or cut in two by a buzz saw or brained by a brick falling from a chimney.

It is really horrible to read the report made to Governor Wiltz.

Of perhaps more than three hundred murderers for many of these murders were committed by several persons - only three escaped from justice. What became of the rest? Where are the three hundred?

One hundred and sixteen were declared NOT GUILTY. A nolle prosequi was entered in fifty-nine cases.

In nine cases it was "not a true bill."

There were three mistrials.

Twelve cases were transferred to the dead docket.

Without going much further into particulars we need only remark that the rest mostly escaped with light sentences, or were pardoned out of the Penitentiary.

Only five murderers were punished by death. And that was only because they were strangers, Because they had no money to pay lawyers, Because they had no political influence.

Two Italians, two negroes and a Malay - probably less guilty than some who are now walking the streets!

There are nearly three hundred unavenged dead, the blood of nearly three hundred victims crying vainly to heaven for vengeance!

If the dead are not indignant, in the immortal words of our Administrator, they ought to be. 


\title{
A Creole Mystery
}

\author{
Item, October 6, 1880
}

They came together from Havana, mistress and servant. The mistress had a strange and serpentine sort of beauty; - the litheness of a snake in every movement; - the fascination of an ophidian; - and great eyes that flamed like black opals. One felt on meeting her that the embraces of lianas and of ivy were less potent to fetter than hers - and to fetter forever. Her voice was remarkably sweet, but had strangely deep tones in it; - and her laugh caused a feeling of unpleasant surprise. It was a mocking, weird, deep laugh, uttered without any change of features; there was no smile, no movement of the facial muscles; the lips simply opened and the laugh came pealing from her white throat, while the eyes, large, brilliant, and sinister with mockery, fixed themselves with motionless lids upon the face of the person present. But she seldom laughed.

None knew who she was. She was a mystery to the French people of the quarter. Her rooms were luxuriously furnished and hung in blue satin. At long intervals strangers called upon her - men of olivaceous complexion and hair tropically black with dead-blue lights in it. They spoke only in Spanish; and their interviews lasted far into the night. Sometimes they seemed to be gay. Gossipy people said they heard the popping of champagne corks; and a perfume of Havana tobacco floated out of the windows and hung about the shrubbery that enshrouded the veranda. 
Sometimes, however, there were sinister sounds as of men's voices raised in anger, and at intervals the deep laugh of the mysterious woman, long and loud and clear, and vibrant with mockery.

The servant was a mulattress, tall and solidly constructed as a caryatid of bronze. She was not less of a mystery than her mistress. She spoke French and Spanish with equal facility, but these only on rare occasions. Generally no mute in the seraglio of a Sultan could be more silent or more impassible. She never smiled. She never gossiped. She never seemed to hear or to see; yet she saw and heard all. Only a strange face could attract her attention - for a brief moment, during which she gazed upon it with an indescribable look that seemed potent enough to burn what it touched. It was a look that made its living object feel that his face was photographed in her brain and would be equally vivid there fifty years after. The foreigners who came were received by her in silence and without scrutiny. Their faces were doubtless familiar. None of them ever spoke to her. She seemed to be more than a Doppelgänger, and to appear in five or six different rooms at the same time. Nothing could transpire unperceived by her; though she seemed never to look at anything. Her feet were never heard. She moved like a phantom through the house, opening and closing doors noiselessly as a ghost. She always suddenly appeared when least expected. When looked for, she was never to be found. Her mistress never called her. When needed, she appeared to rise suddenly from the floor, like those Genii of Arabian fables summoned by a voiceless wish. She never played with the children; and these hushed their voices when 
she glided by them in silence. With a subtle intelligence seemingly peculiar to her, she answered questions before they were fully asked. She never seemed to sleep. Persons who visited the house were as certain to meet her at the entrance three hours before sunrise as at any other hours. She appeared to be surprised at nothing, and to anticipate everything. She was even a greater mystery, if possible, than her mistress.

At last the swarthy foreigners called more frequently and the interviews grew stormier. It was said that sometimes the conversations were held in Catalan; and that when Catalan was spoken there were angrier words and wickeder laughing. And one night the interviews were so terrible that all the old-fashioned French folks in the quarter put their heads out of the windows to listen. There were sounds as of broken glass and passionate blows given to the mahogany table. And the strange laughter suddenly ceased.

Next morning the postman calling to deliver a registered letter found the rooms empty. The spectral servant was gone. The sinister mistress was gone. The furniture was all there; and the only records of the night's mystery were two broken glasses and stains of wine on the rich carpet. The bed had been undisturbed. The clock still ticked on its marble pedestal. The wind moved the blue silk hangings. A drowsy perfume of woman lingered in the rooms like incense. The wardrobes retained their wealth of silks and laces. The piano remained open. A little Angora cat was playing with a spool of silk under the table. A broken fan lay on the luxuriously padded rocking-chair; and a bouquet of camellias lay dying upon the mantelpiece. 
The letter was never delivered. The rooms remained as they were, until mould and dust came to destroy the richness of their upholstery. The strangers never came back, nor did any ever hear what became of them. The mystery remains unexplained. The letter remains in the dead-letter office. But I would like to open it and find out what is in it; - wouldn't you? 


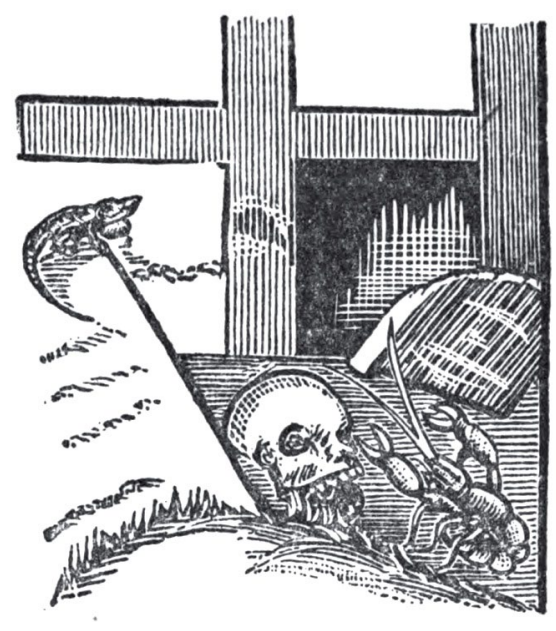

\section{Whited SEPulChRES}

\section{Item, September 9, 1880}

It is rather ghastly to have death in the midst of life as we have it in New Orleans; but ghastlier when it is presented without even the ordinary masks. The skeleton of our public closet is exposed to broad daylight. Are we becoming like the Orientals who never repair? do we accept all things with the fatalistic Kismet? Our bat-haunted prisons and our ruined cemeteries seem to answer in the affirmative.

They are hideous Golgothas, these old intramural cemeteries of ours. In other cities the cemeteries are beautiful with all that the art of the gardener and the sculptor can give. They are often beautiful parks, in which shafts of rosy granite or pale marble rise in 
pleasant relief against a background of ornamental shrubbery; - birds are singing in the trees; - flowers are growing upon the gently swelling eminences which mark the sleep of the dead. There horror is masked and hidden. Here it glares at us with empty sockets.

The tombs are fissured, or have caved in, or have crumbled down into shapeless masses of brick and mortar; - the plaster, falling away, betrays the hollow mockery of the frail monuments; - the vases are full of green water and foulness; - the flowers are dying in their coffins of glass; - the crawfish undermine the walls to fatten upon what is hidden within; - and instead of birds, the tombs are haunted by lizards.

If we must have intramural cemeteries, at least let them be worthy of a civilized people. As they are, they are nightmares. 


\title{
ELEUSIS
}

\author{
Item, November 12,1880
}

Cool, soft light broken by curtains of lace; antiquated and elegant upholstery; a four-columned Creole bed, generously wide and lofty, its lace-fringed pillows embroidered with a rosy monogram; matting checkered in light colors; a bronze clock bearing the nude figure of Ariadne riding upon her loving panther; a glimmer of satin flung carelessly over fauteuils and sofas; a mysterious perfume of woman; a sense of some one absent, and a consciousness of wicked intrusion on the part of the writer - feelings intensified by the merciless ticking of the French clock: - this was Eleusis!

And the Mysteries?

$\mathrm{Ah}$ ! the pretty mysteries; the dainty, soft, delicate, fragile, feminine mysteries! Fairy gauze and butterfly-satin, and moth-velvet and foamy lace and frosted silk, and that white samite - mystic, wonderful - which invites the hand to touch it with a timid caress, and the name whereof is only known to Woman; - and over all a hovering perfume - the perfume of youth, the odor of all that is sweet and feminine, the ambrosia that haunts the presence of Loveliness and clings to her robes - the frankincense of the Shulamitess!

This was the shadowy nook where the human butterfly nightly prepared to issue from her pallid chrysalis; the chamber where the pretty witch spun her web of magical gold. 
"My thread is slim, my thread is fine.

But he must be

A stronger than thee

Who can break this thread of mine."

And the reader murmureth, perchance, that he is yet no wiser than he was before.

Behold! the mystery into which we would initiate thee, $\mathrm{o}$ reader, is a mystery of bayadères, a mystery of dancing girls "robed only in a fleecy cloud of veils," that mystery of the daughter of Herodias which made the king swear a great oath that he should give her all that she desired, even unto the half of his kingdom.

When thou beholdest the dancing girl coming forth to dance before the bow-curving line of lights; - when thou beholdest her poised in air, shimmering in foamy laces and creamy satin like some splendid insect; when thine eyes are dazzled by the witchery of her feet so that thou even wishest to be a Herod that thou mightest offer her, not the half, but in sooth the whole of thy kingdom - dost thou not often marvel at the mysteries of her garb? - enticing only to deceive coquettishly - seemingly light as a Coæ vesta or a ventus textilis such as Egyptian dancers wore, yet faithfully guarding its secrets - thin as a dragonfly's wings, yet subtle enough to withstand the long strain of a pas de séduction? Let us, then, abandon the romance of idealism and descend to the level prose of explanation.

In dressing for the ballet, the fair dancer must disrobe as completely as for the bath. A thin and very 
short chemise is the first article put on. It is peculiarly shaped, cut low, and has pieces to support it from the shoulders. Then the ordinary corset is put on. Then come the tights.

The tights are of flesh-colored silk, and all in one piece. They take the place of stockings and drawers, and are brought up over the hips and fastened with soft but strong tape above the waist and even over the corset. The whole body up to the bosom is gloved in them. If nicely adjusted, and not too often worn, their own elasticity keeps them from wrinkling.

Over the tights a pair of muslin drawers are worn, about as narrow and short as a boy's bathing-drawers. These are of gossamer lightness, but exceedingly white. They are worn for moral reasons.

Over the drawers are six of the lightest petticoats of tulle or tarlatan, whereof it is possible to conceive. These are all attached together at the waistband, so as to form but one piece. Light as they are, their number and starchiness enable them to preserve the graceful shape which gives the ballet dancer the appearance of some beautiful white fly.

Over the six petticoats a seventh, often equally light, but of much more brilliant material, is worn. Sometimes it is decked with flowers, sometimes fringed with lace; sometimes it is white; sometimes it is pink, scarlet, purple, or other color, according to the character of the drama. In Spanish or Italian dances it is very brilliant.

A corset of soft white satin is next put on over the tights and under-corset. Over this is worn a bodice of lace, of silk, of velvet, or other material, according to 
the character of the dance. In ordinary ballet dances, however, all is white, even the slippers.

O the pretty little slippers! They have no heel, and are of the lightest imaginable; - white or pink satin. The uppers are heavily stitched with cotton all about the sole, so as to protect the satin wherever the pressure of the foot flattens it to a level with the leather. At the toe, where the main pressure is, the stitching is so thick and heavy as to form a pad. The slipper catches the heel firmly and is further secured with strong tape.

And then the dancer is attired. The coiffure is a separate matter, and varies according to circumstances.

But, alas! the little slippers can be used only once or at most twice; the tights must be frequently renewed; the tulle petticoats must be incessantly replaced; nearly all this fragile fairy costume continually demands renovation. The laces and upper ornamental apparel alone endure. So that every dancer must carry with her quite a little shoe-store; for in one opera season many dozens of shoes are worn out, and then they are useless, except for rehearsals.

And now our Eleusis having been sufficiently explained, we do propose to say nothing more upon the subject, and leave the reader to dream of - whatever he pleases! 


\title{
LAtin AND ANgLo-SAxon
}

\author{
Item, November 24, 1880
}

The French papers in Canada have latterly warned their readers that the Canadian French are being slowly but surely absorbed by the Anglo-Saxon element, and have been advising them to push forward into the valley of the Ottawa and there found settlements. This may possibly be done; but the end will, no doubt, be the same. The Canadian French have, nevertheless, been among the most thrifty, energetic, and enterprising pioneers in the world; certainly no other men with Latin blood in their veins ever showed more endurance and daring than the famous coureurs des bois and chasseurs de loutre. If the French Canadian is to be absorbed by the Anglo-Saxon element, we cannot avoid asking ourselves what chance the French element of Louisiana can have to resist absorption when the flood of emigration begins to pour southward with the advancing lines of railway?

The chances, in our opinion, are rather in favor of the Canadian French resisting longer than our own Creoles - unless the French element should be kept up by a continuous immigration. Old manners and customs and dialects and families endure longer in a severe Northern climate than in a semi-tropical land like our own. As we near the tropics decay becomes more rapid - not only material decay of substance, but decay of social conditions and institutions as well. Our French element is not composed, however, of such stern stuff as the French people of Canada. They have 
become semitropicalized here; - they have felt the enchantment of a climate of perennial mildness, and have lived for generations under very different conditions to those which have hardened and invigorated the French people of Canada. It must be remembered also that the French Canadians have had to resist the strongest absorbing influences possible - those of the English, Scotch, and Irish elements in all their purity and force. The geographical position of Louisiana, her climate, and her comparative isolation only recently broken by new railroad lines, have aided the Louisiana Creoles in maintaining their individuality and their pleasant old-fashioned manner of existence.

We have often attempted to analyze the cause of the undoubted predominance of the Anglo-Saxon race wherever it plants itself. Many causes have been adduced, but none seem to us satisfactory. The Latin races are not less hardy and enduring, though inferior in physical strength. They are not less intelligent, though less self-denying. They are not less patriotic, though more cosmopolitan. They possess a number of sterling qualities which are wholly foreign to Anglo-Saxon, Teutonic, or Scandinavian character. In our opinion the real secret of the predominance of Northern races lies in the same causes which may partly account for the conquest of the Western Empire by the Goths, after the Roman armies had been fairly worn out in repelling barbaric invasion. The Northern races are far more prolific than the Latin. The Germans of to-day, for example, are filling up America with emigrants. What Latin race can send out such armies of emigrants? Probably not all the Latin races together 
could do so! The fact is not perhaps flattering to the Northern races of Europe; for it is said that the lower organizations propagate most rapidly in all the orders of nature. But history confirms the fact that the real strength of a people lies not in valor and endurance alone, but in its capacity of self-multiplication. Nor is this comforting to think of when we gaze toward China. Idea is stronger than force for a time only; force at length will carry all before it. 


\section{The Flower-SelLers}

Item, September 11, 1880

They sit forever under the shadows - silver-tressed and ancient - calmly weaving their flowers into rainbow-tinted gifts for youth and beauty.

And I, gazing upon them impassibly weaving the bright blossoms together, dream of the ancient Norns of Scandinavian legends -

Weaving the warp and woof of human destinies; - measuring terms of life as the stems of flowers are measured; -

Mystically mingling Evil with Good; Joy with Sorrow; Love with Grief; - tints of Passion with tints of Melancholy, - even as in a bouquet the hues of a hundred flowers are blended into one rich design.

Evanescent as the beauty of Woman are the colors of the flowers; - volatile their drowsy-sweet odors as the perfume of youth.

And thou, O reader, when thou receivest, from the wrinkled hands of the Norns, who measure the lives of summer blossoms, an odorous gift for the ivory hand of thy living idol, -

Knowest thou that the gift is in itself a voiceless symbol of the fragility of all which thou worshippest?

Fair girl, a mightier Norn than that grey woman who silently weaves her flowers in the sun, has measured the golden thread of thy life: -

Though sweeter than the presence of Esther, bathed six months in palm-oil and rich odors before entering 
the chamber of the King - thy youth will pass like the breath of a flower; -

Though thy lips be as those of the Shulamitess, they will wither and crisp and wrinkle like the petals of a scarlet blossom; -

And as a flower between the leaves of a book, thou shalt be pressed between the marble covers of that ponderous volume in which Death, who is, alas! strong as Love, keeps the weird record of his deeds. 


\title{
A Visitor
}

\author{
Item, November 26, 1880
}

"Juan Guerrero y Marquez, su servidor de V."

There are voices which surprise by their sonority. The voice of the speaker, as he introduced himself, made us lift our eyes in surprise to his face; it was a soft roll of thunder, the richest and deepest bass that had ever vibrated in the writer's ears. To have heard it without seeing the speaker would have compelled the idea that it came from a chest of prodigious depth, from the torso of a giant. Not so, however. The speaker was a young and rather slender man, firmly knit, but with more grace than apparent strength in his frame; not over tall, but with a bearing as proud as his Spanish name. He spoke with the refined accent of Madrid, and the words came from his lips with such a musical depth as when the longest strings of a great harp are touched by strong and skillful fingers. The face was characteristic a true Latin face, with the strong keenness of the Roman eagle in its profile; eyes large and brilliant as a falcon's; eyebrows thick as mustaches, rising toward the temples, with a slightly sinister elevation; mustaches curling up toward the cheek-bones; and such a short black pointed beard as we see in the portraits of Velasquez. This handsome and daring face belonged to a beautifully formed head, covered with the blackest curls possible to conceive - the head of an antique Roman soldier set upon a columnar neck. With the clear bronze of his skin, no more striking 
type of the finest of the Latin races could have been asked for by a painter.

Artista español de los primeros, he had been travelling with a Spanish opera company through the West Indies, and enchanting the señoritas of Havana with the magic of his marvelous voice. Now he wished to visit some distant relatives in one of the far South American republics - members of his own Spanish family and bearing his own name, but born under the Southern Cross. He had never seen them; but strangely enough the ancestral family in Spain had maintained relations with its tropical children for a hundred years.

"And there is really a consul of that republic in New Orleans?" we asked in bewilderment; for, alas! we had never heard of him.

"Ciertamente, señor!"

So we went to find the consul. It was necessary, first, to find out who he was, and where he lived. The directory refused to yield up the desired information. Then we went successively to see a Spanish tobacconist and a Spanish wine merchant and a Spanish doctor and a Spanish apothecary and a Spanish journalist - who was not at home - and a certain Spanish lady who lives upon a street bearing the name of an ancient Spanish Governor.

It proved easier, however, to find who the consul was than to find where he resided. At one time we began to fancy that he was an illusion or a phantom. Seven different places did we visit in which he had formerly resided, but resided no longer - so that we felt even as wayfarers who vainly pursue after a will-o'-the-wisp. 
And a young woman passed by, graceful as a panther, carrying a basket upon her arm. Her eyes were very large and black; her skin the color of gold; and her figure owned those indescribable curves, that cambrure de taille for which there is no expression in the English tongue.

"Que es bonita!" exclaimed the singer, with a caressing accent in his deep voice. If the woman did not hear the compliment, she had at least heard the Spanish tongue; for she suddenly turned, and, poised in an attitude of supreme grace like a statue of bronze, addressed the artista in a voice clear as a silver bell: - “A quien busca V., señor?” And their black eyes met. It was a tropical look: the man fascinated by the serpent grace of the woman; the woman not seeking to conceal her admiration of the handsome youth before her. Yes: she knew where the consul - Señor Don Alejandro - lived. It was just at the corner. "Mil gracias, señorita!" Not a Spanish girl, no - from some strange town with an Aztec name in the heart of Mexico. "Yo estaba allá!" cried the artist joyfully: "I remember it well - the plaza, and the old house of Señor - on the corner, where I spent some very pleasant days when I was traveling through Mexico." And then recalling old memories, they forgot for a moment all about the distant South American republic and the phantom consul. Adios - a clasp of olive-skinned hands; and with the oldfashioned and tender commendation to God, they departed, never to meet again - as seabirds flying over the sea to opposite coasts look into each other's eyes a moment and pass on. 
"I have been to your opera," he said, "I like it. But neither the French nor the Italians know what the Spanish theatre is. It is not merely music and drama. It is a school. It is a medium of national instruction. It teaches feeling, expression, deportment, dress, courtesy, taste, appreciation of the beautiful. And that is why Spanish audiences are so difficult to please."

"I wish I could hear you sing," we said.

"Lo me gustaria mucho," he returned; "but I leave to-night. And you could not judge of what I can do unless you should hear me in the theatre. Do you smoke?" And he presented us with a real "puro."

Suddenly an organ at the corner struck up a fragment of Faust - the Gloria chorus of the soldiers. "Ah! I love that," he murmured; and suddenly the martial air rolled from his lips in tones rich and deep, but golden-clear as the voice of a mighty organ. It was only for a moment; but in that moment the children ceased their dances, and people passing through the old-fashioned streets paused and turned and wondered at the witchcraft of that marvelous voice.

"Adios, señor!" And we parted forever. 


\title{
Creole Servant Girls
}

\author{
Item, December 20, 1880
}

Creole colored servants are very peculiar. They are usually intelligent, active, shrewd, capable. They generally perform well whatever they undertake. They are too intelligent to be dishonest, knowing the probable consequences. They comprehend a look, an expression, as well as an order; they will fulfill a wish before it is expressed. They see everything, and hear everything, and say nothing. They are consummate actresses, and can deceive even the elect. They can ape humility, simulate affection, pretend ignorance, and feign sorrow so that the imitation is really better than the reality would be, and serves the same purpose. They can tell a lie with the prettiest grace imaginable, or tell a truth in such a manner that it appears to be a lie. They read character with astonishing quickness, and once acquainted with the disposition of their employer will always anticipate his humors and make themselves pliable to his least wish. They are the most admirable waiting-machines which ever existed; absolutely heartless, without a particle of affection or real respect for an employer or his children, yet simulating love and respect so well that no possible fault can be found with them. Once initiated into the ways of a household, it is seldom necessary to give them an order. They know everything that is required, and everything is done. If regularly paid and well treated, they will remain in a family for a generation. They 
demand a great deal of liberty when not actually employed, and will not remain in a house when they are not wholly free after working hours to go out or in as they please. They know everything that is going on, and a great deal more than they have any business to know. If they consider their employer discreet, they will furnish him unasked with the strangest secret news. They possess family histories capable of doing infinite mischief, but seldom make use of them, except among each other. To strangers they are absolutely deaf and blind - neither bribes nor promises will extort information from them when asked by persons they do not know. They can keep people at a distance without offending; and become familiar to any extent without making themselves disagreeable. They can be superlatively vicious, and yet appear to be supremely virtuous. They can also be dangerous enemies - and there is no denying the fact that their enmity is to be dreaded. They speak several languages, and sing weird songs. They will do anything that any imagination can conceive for money; and are very friendly, indeed, as long as the money holds out. They are actually very cleanly, oddly superstitious, and very diligent. They have a way of working very hard without appearing to work, and of doing little or no work while appearing to be working themselves to death. Their virtues are simply the result of a great natural shrewdness, which appears to have been handed down from old times, with the Latin blood that beats in the veins of French-speaking quadroons and mulattresses. They will not steal; but they have no moral scruples when the infringement of morality does not involve 
public disgrace and legal punishment. They do not like American or English-speaking people; and it is probable that none but Creoles know how to manage them. The type is fast disappearing; but it certainly affords one of the most extraordinary studies of human nature possible to conceive. 


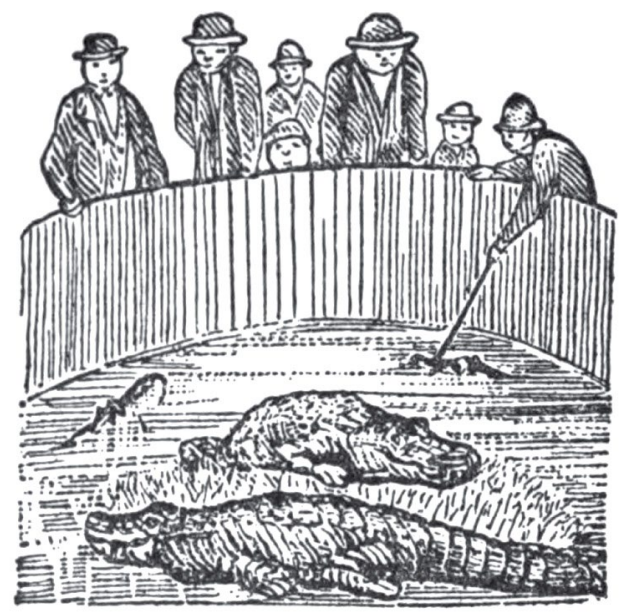

\section{The Alligators}

Item, September 13, 1880

None discover aught of beauty in them; yet they were once worshiped as gods.

They were not of this world, in truth, but of another - the Antediluvian world of monsters and dragons and vast swamps broader than continents - where there were frogs larger than oxen, and alligators longer than the serpent slain by the army of Regulus.

The Ichthyosaurus, the Pterodactyl, the Megatherium, the Plesiosaurus - have passed away with the Antediluvian world.

This strange being, with its dull cuirass marked like the trunks of the primeval tree-ferns, still endures although new strata have been formed since the birth 
of his species - although the monstrous vegetation of the swamps in which his ancestors crawled has been transformed to beds of coal!

Alligator, crocodile, or cayman - it matters littlethey alike belong to the age before which history began.

And looking upon them, must not one dream of the sacred Ganges and the most ancient Nile - of South American rivers that flow by dead palaces buried in the vegetation of virgin forests - of dead civilizations - of Karnac and Thebes and Crocodilopolis - of catacombs and broken-limbed colossi - of empires and of races that have been swallowed up by Time? The world has changed, but the Giant Lizard changes not. 


\section{HoME}

Item, January 8, 1881

We have all heard curious things said about the peculiarities of New Orleans; we have heard that it was a city where the sun rose in the west and water ran uphill; we have heard it spoken of as built upon a dunghill, and there is a Spanish proverbial expression about it still more uncomplimentary, often uttered by West India captains, which we dare not cite, even in the original. But yesterday we received a visit from an old resident of thirty years' standing, who in the course of a conversation summed up his opinion of New Orleans with the phrase: "New Orleans is a city where it is impossible to make a home for one's self without marrying. I have tried for thirty years to make a home here, and failed." And this observation set us to meditating whether this were, indeed, owing to any peculiarity of the city, or to that vague longing for the quiet comforts of a household which all bachelors feel as life creeps by and each succeeding winter adds its frost to their beards. To the latter, we trust; for we wish to think well of New Orleans.

There is one thing certain: a rich man who understands what the comforts of life are may make a home for himself anywhere without marrying. But rich men form exceptions to the general rule governing human lives, and we are constrained to consider the matter from the standpoint of those who are not rich, and who must expect for the greater part of their lives to work for others, however independent their capacity 
as artisans or talent as professional men may render them. The more sensitive their disposition and the more artistic their ideas, the more difficult, of course, must it be for them to obtain a home conformable to their desires whether married or unmarried. If unmarried, they may expect to have a hard time of it in any city, if compelled to live there for a number of years. Luckily for themselves, many such men are of wandering dispositions. They soon tire of a city; pack up and go elsewhere, after refusing good offers or neglecting first-class chances of becoming wholly independent by remaining. Being rolling stones, they gather no golden moss; and change of scenery and climate, new places and new faces, new friends and strange experiences become for them almost a necessity of life. These are the world's Bohemians. They are a class apart. They enjoy life, too, in a peculiar fashion which the generality of quiet people of regular habits do not understand. But there are many who, desiring to continue single, and obliged to live where fortune has cast their lot or run the risk of losing all and beginning the struggle with the world over again, do forever pursue after the chimera of a home, and cannot understand, until they have tried all possible expedients and suffered all varieties of disappointments, why they cannot make a home for themselves. To such as these, of course, the idea of a home is coupled with memories of the home of one's youth - cozy rooms, quiet, good fare, kindly attention, liberty to act and think, something to regret leaving, and to delight returning to of evenings; - a pleasant greeting, a dog barking with joy, a cozy chair by the fire, and a cat purring on the rug. And 
yet how one can obtain these things without a woman's ministry nobody has ever pretended to explain. A woman is the soul of home; and without her there is little more than furniture and brick walls there. She transforms and beautifies everything. You may poohpooh and hum-hum! - but you cannot explain how the comforts of a home - a home such as the term was explained to us in childhood - can possibly be obtained without the presence of woman. Without her one may be said to live at such and such a place; but to say that "he has his home there" is sheer humbug. He has no home!

Consequently many really marry just to obtain a home - which is foolish enough, although the natural consequence of social conditions. We remember one case in this city - a young Frenchman who was continually changing his quarters for years, never being able to find rest or comfort in any one house. At first he had quite a number of effects; but these he gradually disposed of, because they proved serious impediments to his nomadic life, until at last his baggage consisted of a newspaper bundle and a box of matches. His marriage proved unhappy enough in the end. He drew an unlucky number in this great life lottery of ours. But to return to the point under consideration: what home is there for men circumstanced like those we spoke of? Boarding-houses do not offer any. Boarding-houses are good and necessary institutions - but there is no home life about them. No man who longs for home comforts can live in any one boardinghouse beyond a certain length of time, or in a hotel. There is no privacy, no seclusion; one is always being 
brought into contact with persons whom one does not care to know, and obliged to endure things which one does not like to stomach. Life in a private family is better; but, of course, the private-family boarder is always made to feel that he is not one of the family, and the manner of making him feel it is not the most agreeable thing in the world. Renting furnished rooms and boarding in restaurants, or "boarding around" as they call it, is vanity and vexation of spirit, and costs about as much as hotel fare without rendering one any more independent. Furnished rooms! - Furnished rooms! It is an awful, awful subject - too awful to dilate upon! Neither is there any stability about such a method of living. If one does find just what suits him, he can never tell how long it will last; but of one thing he must always be sure - that the better it seems the sooner something dreadful and unexpected is going to happen. And then?

Well, when you have become tired of boardinghouses and restaurants and furnished rooms, you may try renting or buying a house of your own and furnishing it. But a man must have something round the house, if it is only a dog, to keep him company. And he must also have somebody to take care of his rooms. If he gets a housekeeper, to avoid scandal he must get the oldest and ugliest woman he can find. And servants and others victimize the bachelors terribly. Moreover, everybody living near such a man will regard him as a lunatic or an original, and treat him accordingly. The hand of society is raised against the man who tries to live alone in a house of his own unless he be very rich. Sometimes five or six bachelors 
get together, as we have known them to do in the French quarter, furnish a house, hire a housekeeper, and live a sort of club-life by themselves. But if they should fall out, the whole arrangement would prove more disagreeable than all the combined afflictions common to furnished rooms and boarding-houses.

There is no consolation. To get a home, one must get rich or marry, and even then he may not be lucky enough to get it. 


\title{
Old-Fashioned Houses
}

\author{
Item, January 12, 1881
}

Probably there are as fine residences in New Orleans as in any other city of equal population in the United States; and the almost tropical beauty of the grounds and gardens which surround them lends them a charm that cannot be found in many other cities of North America. Most of these fine residences are built upon designs entirely different from the prevailing architecture of New Orleans houses; and it is pleasant to observe that a new style of building even small houses is coming into fashion in different parts of the city. Few of us can afford to live in palaces; and excepting residences that are absolutely palatial, there are very few comfortable dwellings, comparatively speaking, in the Crescent City. There is much picturesqueness; but picturesqueness is not comfort: there is much of outward charm in old- fashioned places, in quaint rooms, in audacious balconies, in mediæval-looking dormers, in peaked roofs, in maisonettes tinted lemon-yellow, pale rose, or faint green; but all this does not give the coziness of a home. The New Orleans of half a century ago is not suited to the wants of the New Orleans of to-day. The population has increased; there are infinitely fewer rich people here than formerly; there are many more inhabitants to the square mile, and the great houses which formerly constituted the winter residences of wealthy planters and others must now be portioned out among many families or transformed 
into boarding-houses in order to be made profitable to their owners. A change in the old style of building dwellings is becoming more and more imperative every succeeding year.

The causes of the old style of building are attributable to a wholly different social condition which still existed a generation ago; and there is really no reason why it should survive at present. Nevertheless, we frequently see new houses in process of erection, being constructed upon precisely the same uncomfortable and antiquated plans which should be abolished forever. We have nothing to say against the outward appearance of New Orleans houses. The general effect is very pleasing; - no one with an artistic eye can avoid loving the zigzag outline of peaked roofs with the pretty dormers; the iron arabesques of graceful balconies, the solid doors and burglar-proof shutters, so brightly green. The old-fashioned houses are by no means ugly. But their interior arrangement is altogether condemnable and renders them almost unfit for modern homes. Take, for example, the ordinary double cottages of which there are thousands upon thousands in New Orleans. Not only do all the rooms open into each other, either with large folding or sliding or the ordinary doors; but each room of each house often opens into each room of its twin on the other side. Thus there are from two to three doors to each room, besides windows; rendering it difficult to warm any apartment in a damp New Orleans winter. Privacy is impossible; seclusion a mockery. Even the attics of two houses open into one another. Suppose one is looking for a house, and expresses his dissatisfaction with 
this plan, the proprietor will exclaim with astonishment: "Why! there is a door; and the door is closed!" A thin door does not ensure seclusion or even quiet. Every sound can be heard distinctly in both houses the crying of children in the night; family quarrels; noises of household work; and many other things which should not be heard at all. And the doors are not even double. In nine cases out of ten daylight shows through them. The same thing renders it very difficult to obtain comfortable furnished rooms in the city. Every room opens into another; and every movement of one's neighbor or neighboress is distinctly audible. All this might be avoided by the construction of hallways; and certainly it is not for want or value of space that we have so few hallways in the city. Immense rooms, high and airy! - but cold and comfortless - opening into other immense rooms - all opening into other houses: of such there is no end.

Now if there is one thing more essential than any other to the comfort of a house, it is seclusion! The English understand this fact even better than the Americans, and their cottages are model homes. When a man enters his house he wishes to be able when he pleases to shut himself up from the rest of the world, to be alone with his family or with his thoughts, to rest himself after the day's anxieties without further turmoil or annoyance. But how is he to do this when he finds only a partition thin as the cover of a novel between himself and others who are not of his family, and who live practically on the same floor and almost in the same room? If he wishes to enjoy an hour in his private study, it is not pleasant to be obliged 
all the time to listen to noises in the next room, even if made by his own servants or his own children. For members of a family themselves require at times to seclude themselves from other members of the family; - there are business matters to be talked of; there are projects which children or servants should not hear; there are numberless things which the heads of a household wish to discuss by themselves. And to warm such houses in winter there must be a fire in every room upon the same floor; otherwise one will find that folding doors are a mockery and sliding doors a vexation of spirit. The double cottage is an abomination; and even the single cottage without a hallway is an affliction. Is it agreeable to be unable to go to bed either without passing through somebody else's room or having somebody else passing though your room? It is not even a civilized way of living; and certainly a vast majority of New Orleans houses would appear to a stranger to have been constructed with little regard to common decency. The truth is simply that twentyfive years ago people here lived very differently from what they can afford to do now; - everything was on a larger and more generous scale; and perhaps the dwellings were excellently adapted at that time to the wants of their tenants. To-day all is changed. Picturesque and uncomfortable New Orleans must disappear to give place to one perhaps less outwardly attractive but less illusive and more substantial. The result will certainly be less consumption and less rheumatism. 


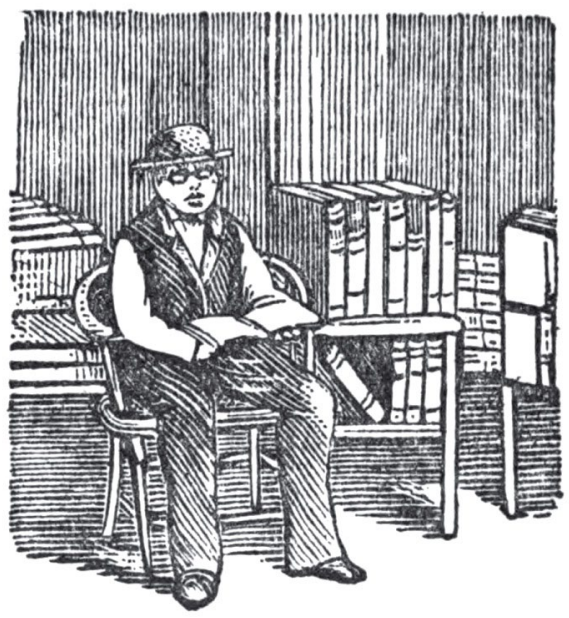

\title{
The Vendor OF WiSDoM
}

\author{
Item, September 15, 1880
}

The Vendor of Wisdom selleth and also buyeth at a moderate price all the wisdom that hath been crystallized into the shape of books.

In his antiquated and darksome little shop, the thoughts of thirty centuries reside.

Every wave of civilization that has ebbed over the face of the earth, has drifted something into that little dusty bookstore.

Every great event in the history of the earth has contributed a something to those dusty shelves.

All nations and tongues are represented there; all the philosophers have riches there; and there all the poets have preserved their word-music. 
As for the antiquarian, he thinketh much of these things; for he knoweth by heart the story of each book, and now rarely openeth any save new ones - works of this age of ours.

Then he saith-

"Pshaw! They call that new, and I have beheld the same in books that were written lo! three thousand years ago!

"The founders of the Semitic and Aryan religions knew these things; and forsooth these modern fools offer them to us as something novel!

"The Egyptians were versed in the very profoundest philosophy of all these questions; - they were taught also in Rome and in Greece.

"Nevertheless, there are people in these days who imagine they can write something new upon the subject."

And saying these things he putteth the new book aside, and he taketh a duster and dusteth tenderly the thoughts of Plato and Aristotle and Socrates, and patteth the good old books on the back.

Never doth he lose patience - not even when bibliophilists steal his books -

Nor when cockroaches devour the backs of Aristophanes and Pliny, and of Diodorus Siculus, of Athenseus and Sophocles and Petronius -

Nor when bookworms bore holes through the Elzevir text of the Fathers of the Church -

Nor when, having bought a book for a good price, he afterward discovereth that the person who sold it to him had previously torn out the engravings -

Nor even when having been told to "lay books 
aside," the person for whom they are laid aside never cometh back - so that they lay there until all hope of selling them has departed.

He putteth works of godly piety in the waste-basket.

And books in the French language, robed in yellow like Roman courtesans - these he selleth for a good price.

"For such," he saith, "is the depravity of human nature."

Never have I been able to learn whether he saith this seriously or not - so much doth his eye twinkle when he saith it.

He is never absent from his post; - for twenty-five years he hath lived every day with his books from 7.30 A.M. to 7.30 P.M.

And there will he remain, let us hope, for many years more.

Until they take him from his books and file him away, even as a roll of MS. in the marble pigeon holes which are never dusted and whose contents are never looked at. 


\title{
Some Positive Opinions
}

\author{
Item, April 27, 1881
}

In a curiously illustrated edition of Balzac's "Peau de Chagrin" there is a strange and terrible face which some of you may remember having seen: it is the face of the bric-à-brac dealer who sold the mysterious parchment - a forehead of immense breadth; a nose like that of Mephisto in Retsch's outlines; a mouth thin, straight, and passionless; eyes large and sinister, with brows knotted above the nose like adders and rising wickedly toward the temples - in short, a face most sinister, most infernal, but withal fascinating with a diabolic fascination. Now, can you imagine such a visage transformed and softened by youth and femininity, made beautiful without losing its strength of menacing wickedness; the nose a little less rugged, the eyes a little larger, the brows a little lighter? Then you have before you an idea of the dancer's face.

We sat and talked under the fig-tree. At least she talked; I listened under the steady gaze of her basilisk eyes. She seemed to speak all modern tongues fluently; had excited passion by her lithe grace and surpassing skill of limb-curving in half the capitals of Europe. She talked about Havana, Buenos Ayres, Valparaiso, Vera Cruz, Mexico City; described Spanish dances in a mocking way peculiar to herself, speaking all the while in a voice deep and sweet as the lower tone of some reed instrument. But the depth of the voice and its sweetness wrought an unpleasant effect 
upon the listener - such an effect as a wizard's music might have, luring to danger.

"I hate men," she said, with Italian vehemence, and an indescribable gesture of disgust; - "oh, how I detest them! It amuses me when I am dancing to think of all those thousand eyes glaring upon me, as at something they are almost mad to touch and cannot reach, and dare not touch if they could. It gives me pleasure; and often when I smile on the stage the smile is not mechanical; it is prompted by a sense of amusement which is too strong for me to resist. I know that hundreds of young fools will leave the theatre devoured with a wish they cannot gratify. Ah! I hate men!

"Of course you know as well as I do that they pester and torment us. I am burdened with letters, presents - stuff! Love! Ah, bah! In a life such as mine one soon learns what love is worth! I used to read the letters I got. Now I seldom read more than the first line! Presents? Yes, all I want.

"Let me tell you my way of treating the fools. I never answer a letter unless it is accompanied by a present - and the present must have some value. Flowers! - I hate flowers! What good are flowers to me? What value have flowers twenty-four hours after being thrown at my feet? I would be as pleased to receive a jar of ashes or a box of sand. Do you imagine I would pick up their worthless flowers? Never! I can always find some way to avoid that.

"Then I never answer in writing - never! No woman who is not an idiot will do that. I let somebody else carry my message - always worded in such a way that the fool imagines it is the greatest privilege in 
the world to be permitted to see me. When he does see me, he pays dearly for it, if he is worth anything; and if he is not - which I soon find out - he never sees me again - except on the stage. And then it amuses me to know how I can torture him.

"I never say a pleasant word to an admirer. Why, if I did, the fool would really think he had made an immense impression! I have my own special way of treating him; he always brings me a present, of course. I never thank him! Never! I look at it; find fault with it; laugh at it; mock the man; and finally when he does not know what to do, I condescend to lay it aside. That means acceptance. He buys a better present next time; every time he buys me something, I treat him worse than before. Much worse! I have tormented men until they cried - yes, cried: the ridiculous fools!

"No; the worse you treat men, the better they like you! And you know it is all passion - wind and foam and smoke - a fancy - a passing beat of the blood, for which a man would sacrifice my life and happiness if he could and dared! But I know them! I can play with them as an angler plays with a fish! I sometimes let them kiss me if they are not too nasty - or feel my arms and shoulders, smooth me down - you know the way men like to stroke a woman, as if a woman was a cat! But I have a certain respect for myself. I believe in nothing but myself - and my mother, yes! Now, do you suppose I will allow men to make me their puppet, their doll, their kitten, their lemon to be squeezed and thrown away? Bah! I can play salamander. I am a juggler that can handle fire without burning my fingers. I can touch pitch and not be defiled. 
No man can boast of the contrary. There are liars who say such things about all stage characters; but what do I care? I have made men pay well for all that men have said about me.

"Afraid? Pooh! Of what? I know desperate men when I see them. I have not lived and traveled for nothing. And I calculate my time nicely. I know just what I can accomplish during my stay in a city. And do you know that no man has dared to insult my face? I mean coarsely and abusively. They are afraid of me. The secret of success in life is to make people afraid of you. Only fools remain on the defensive. I am always on the aggressive. Insult! - I would poniard a man if I saw a thought of insult in his eyes! Law! What do I care for law? I am a law unto myself. Why, a woman has always the advantage in such cases. Suppose I say: 'That man came to see me under some pretext. He attempted to take advantage; I know how to take care of myself; - I killed him!' Who will contradict me?

"Lover! Nonsense! Perhaps, when I leave the stage! But I shall be mistress. Do you think I would allow a man to say to me, Do this, Do that?

"I forgot what I was telling you- when I allow a man to kiss me, he begins to be elated. He thinks he has an easy road before him. He begins to look confident. He becomes airy. Then the day after I refuse to speak to him, or see him at all! He feels as if struck by lightning. He imagines all kinds of things - that he has been slandered or something. He wants to make an explanation. He becomes pathetically eloquent. $\mathrm{He}$ writes crazy letters. I pay no attention to him. He becomes feverish, furious, frantic, desperate. He would 
sell his soul just to be able to say one little word to me; - one little word would be for him what one little drop of water would be to the tongue of the damned. And he cannot get the chance to speak. He thinks of killing somebody. Then is the time to step in and ask and receive. Finally they learn to hate me. That is just what I want, and this is how I rid myself of them. The Fools!" 


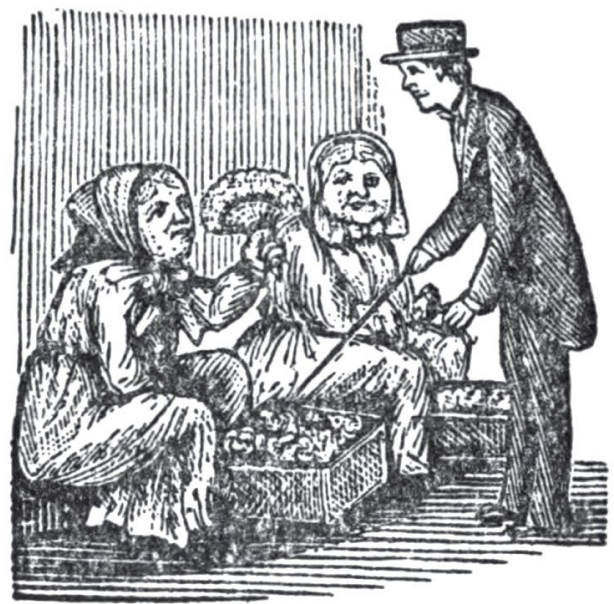

\section{VOICES OF DAWN}

Item, July 22, 1881

A dreadful sound is in his ears. - Job xv, 21.

There have never been so many fruit-peddlers and viand-peddlers of all sorts as at the present time - an encouraging sign of prosperity and the active circulation of money.

With the first glow of sunlight the street resounds with their cries; and, really, the famous "Book of London Cries" contains nothing more curious than some of these vocal advertisements - these musical announcements, sung by Italians, negroes, Frenchmen, and Spaniards. The vendor of fowls pokes in his head at every open window with cries of "Chick-EN, 
Ma-damma, Chick-EN!" and the seller of "Lem-ons fine Lem-ons!" follows in his footsteps. The peddlers of "Ap-PULLs!" of "Straw-BARE-eries!" and " BlackBrees!" - all own sonorous voices. There is a handsome Italian with a somewhat ferocious pair of black eyes, who sells various oddities, and has adopted the word "lagniappe" for his war-cry - pronouncing it Italianwise.

He advances noiselessly to open windows and doors, plunges his blazing black glance into the interior, and suddenly queries in a deep bass, like a clap of thunder, "LAGNIAPPA, Madam-a! - la-gniap-PA!" Then there is the Cantelope Man, whose cry is being imitated by all the children:

\section{"Cantel-lope-ah!}

Fresh and fine, Jus from the vine, Only a dime!"

There are also two peddlers, the precise meaning of whose cries we have never been able to determine. One shouts, or seems to shout, "A-a-a-a-ah! SHE got." Just what "SHE got" we have not yet been able to determine; but we fancy it must be disagreeable, as the crier's rival always shouts - "I-I-I! - I want nothing!" with a tremendous emphasis on the I. There is another fellow who seems to shout something which is not exactly proper for modest ears to hear; but he is really only announcing that he has fine potatoes for sale. Then there is the Clothespole Man, whose musical, quavering cry is heard at the distance of miles 
on a clear day, " Clo-ho-ho-ho-ho-ho-ho-ho-se-poles!" As a trilling tenor he is simply marvelous. The "Coalycoaly" Man, a merry little Gascon, is too well known as a singer to need any criticism; but he is almost ubiquitous. There is also the fig-seller, who crieth in such a manner that his "Fresh figs!" seems to be "Ice crags!" And the fan-sellers, who intend to call, "Cheap fans!" but who really seem to yell "Jap-ans!" and "Chapped hands!" Then there is the seller of "Towwells" and the sellers of "Ochre-A" who appear to deal in but one first-class quality of paint, if we dare believe the mendacious sounds which reach our ears; neither must we forget the vendors of "Tom-ate-toes!" Whose toes? we should like to know.

These are new cries, with perhaps three exceptions; - with the old cries added to the list - the "calas" and the "plaisir" and other Creole calls, we might "spread out" over another column. If any one has a little leisure and a little turn for amusement, he can certainly have plenty of fun while listening to the voices of the peddlers entering his room together with the first liquid gold of sunrise. 


\section{NOTES}

Notes at the foot of the page are by the author or by Charles Woodward Hutson.

18.1 LA DouAnE ] customs house (French)

18.4 Karnac ] temple complex in Egypt with portions dating from the 3 rd millennium BCE.

27.1 Ultra-CanaL ] Canal Street followed the route of a proposed - but never built - canal linking the Mississippi River with Bayou St. John and Lake Pontchartrain. It marked a dividing line between the older Creole French Quarter and the newer Anglo-American neighborhoods to the west.

31.32 cochonnerie ] trash (cochon - pig)

32.15 canaille ] the lowest class of people, the vulgar

32.30 bayadère ] professional female dancer in India

34.6 berceuse ] rocker

34.8 farfadet ] sprites or fairies of French folklore

37.14 Gehon ] one of four rivers issuing from the Garden of Eden

40.24 Choppinism ] Dr. Samuel Choppin was President of the Louisiana Board of Health. He was criticized for allowing commercial interests to limit efforts to control the yellow fever epidemic. See Dennis East II, "Health and Wealth: Goals of the New Orleans Public Health Movement, 1879-84," Louisiana History: The Journal of the Louisiana Historical Association, Vol. 9, No. 3 (Summer, 1968), pp. 245-275.

46.3 Est-ce que vous vous fichez de moi? 'cré nom! ] Are you kidding me? holy name! 
46.18 bêtises ] foolery

48.11 locataire ] tenant

48.13 essuiemains ] hand towels

48.16 vente à l'encan ] auction

60.26 sans foi ni loi ni roi ] without faith, law, or king

69.29 embaralificotée ] embarked, underway

81.5 loquitur ] speaks (Latin stage direction)

81.11 bêtises ] foolery

82.1-2 canaille and racaille and charogne ] scoundrel, scum, and carrion

83.6 berceuse ] rocking chair

83.12 les sacrés voleurs ] holy thieves

83.12-13 Charogne de pays ] country carrion

92.19 aqua Tofana ] poisonous compound of arsenic, lead, and belladonna used in 17th-century Italy

93.25 nolle prosequi ] decision not to prosecute

99.1 Whited SEPulChres ] Mathew 23.27 "Woe unto you, scribes and Pharisees, hypocrites! for ye are like unto whited sepulchres, which indeed appear beautiful outward, but are within full of dead men's bones, and of all uncleanness."

99.8 Kismet ] fate, destiny

101.1 Eleusis ] site of the "Eleusinian Mysteries," the most famous of the secret religious rites of ancient Greece

101.24 Shulamitess ] referring to the female protagonist in the Bible's Song of Songs

102.22 Coæ vesta ] semi-transparent silk garments from the island of Cos (Kos) in antiquity

110.3 su servidor de V. ] at your service

112.4-5 cambrure de taille ] arch of the waist 
112.7 “Que es bonita!” ] How pretty!

112.13 “A quien busca V., señor?” ] "Who are you looking for, sir?”

112.19 "Mil gracias ] A thousand thanks

112.21 "Yo estaba allá!" ] "I was there!"

113.9 "Lo me gustaria mucho,"] "I would like it very much,"

113.11 puro ] cigar made exclusively of tobacco from a single country

117.9 the serpent slain by the army of Regulus ] In 255 BCE, during the First Punic War, Roman general Marcus Atilius Regulus led an invasion of Carthage that was met by a giant serpent or reptile at the Bagradas River. The beast was finally killed by the army and its skin reportedly 120 feet long - sent to Rome.

131.3-4 Balzac's "Peau de Chagrin" ] 1831 novel known in English as The Wild Ass's Skin

131.8 Mephisto in Retsch's outlines ] Friedrich August Moritz Retzsch (1779-1857), German painter, draughtsman, and etcher, was known for his etchings of Goethe's Faust.

134.13 poniard ] small slim dagger 


\section{ABSTRACT}

New Orleans in 1878 was the most exotic and cosmopolitan city in North America. An international port, with more than 200,000 inhabitants, it was open to French, Spanish, Mexican, South American, and West Indian cultural influences, and home to a thriving population descended from free African Americans. It was also a battleground in the fight against yellow fever (malaria) and in the political upheavals that followed the end of Reconstruction. The continued influx of Anglo-Americans and the renewed ascendancy of white supremacists threatened to overwhelm the local blend of languages, races, and cultures that enlivened the unique Creole character of the city. Writing for an English-language newspaper, Lafcadio Hearn presented the speech, charm, and humor of the Creolized natives on the other side of Canal Street, and illustrated his sketches with woodcut cartoons - the first of their kind in any Southern paper. These vignettes, published in the New Orleans Daily Item during 1878-1880, capture a traditionalist urban world and its colorful characters with a delicate and sympathetic understanding. 


\section{About the AUTHOR}

Lafcadio Hearn (1850-1904) was born on the Ionian island of Lefkada to a Greek mother and British Army father. His parents' separation and annullment left him, at age 7 , the ward of a paternal great-aunt in Dublin. She sent him to Catholic schools in Ireland, France, and England, but family bankruptcy interrupted his education and led to his emigration to America in 1869. His promised contacts proved worthless, and he was left broke and alone in Cincinnati, Ohio. He found work there with the expatriot English printer and socialist Henry Watkin and later as a newspaper reporter for the Daily Enquirer. In 1874 he married Alethea Foley, a 20-year-old African American woman (in violation of Ohio's anti-miscegenation law). They divorced in 1877, and Hearn moved to New Orleans where he lived ten years and wrote for several newspapers, starting with the Daily Item in June 1878, and later for national publications Harper's Weekly and Scribner's Magazine. He went to the West Indies as a correspondent 1887-1890, and then to Japan. He married Koizumi Setsuko in 1891, became a Japanese citizen in 1896, adopting the name Koizumi Yakumo, and taught at high schools and universities. His published books on Japanese culture were instrumental in introducing Meiji Japan to an international audience. He was succeeded as professor of literature at Tokyo Imperial University by Natsume Sōseki.

Charles Woodward Hutson (1840-1936) was a Confederate veteran, lawyer, painter, author, and professor of Greek and modern languages at Southern colleges. 
